\title{
Agroforestry for Landscape Restoration and Livelihood Development in Central Asia
}

Dr Utkur Djanibekov, Klara Dzhakypbekova, Dr James Chamberlain Dr Horst Weyerhaeuser, Dr Robert Zomer, Dr Grace B. Villamor, Dr Jianchu Xu 

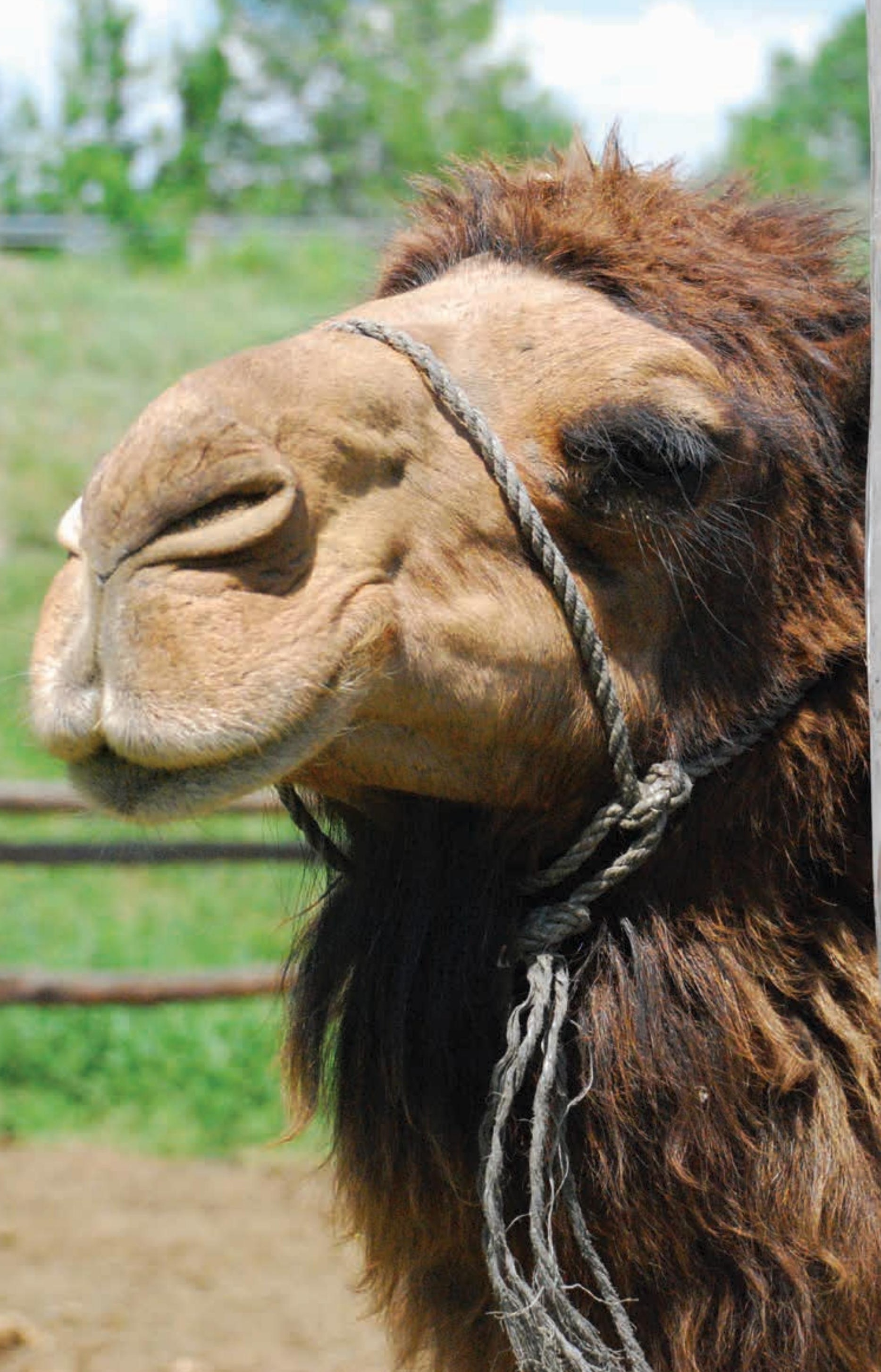


\section{Agroforestry for Landscape Restoration and Livelihood Development in Central Asia}

Dr Utkur Djanibekov, Klara Dzhakypbekova, Dr James Chamberlain Dr Horst Weyerhaeuser, Dr Robert Zomer, Dr Grace B. Villamor, Dr Jianchu Xu

Working Paper 186 


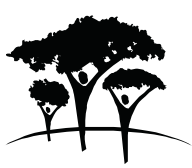

World Agroforestry Centre TRANSFORMING LIVES AND LANDSCAPES

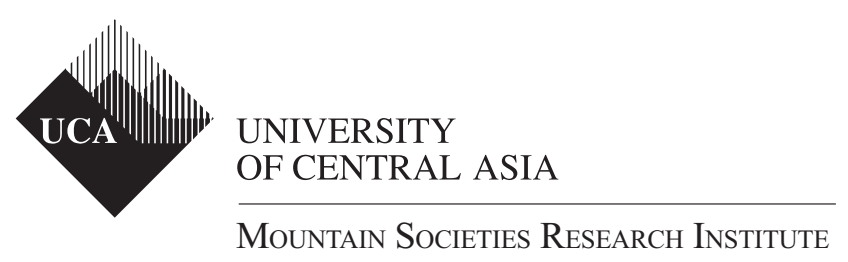

\section{Correct citation:}

Djanibekov, U.; Dzhakypbekova, K.; Chamberlain, J.; Weyerhaeuser, H.; Zomer, R.J.; Villamor, G.; $\mathrm{Xu}, \mathrm{J} .2015$. Agroforestry for landscape restoration and livelihood development in Central Asia. ICRAF Working Paper 186. World Agroforestry Centre East and Central Asia, Kunming, China. $41 \mathrm{pp}$.

\section{DOI: $10.5716 / \mathrm{WP} 14143$}

Titles in the Working Paper Series aim to disseminate interim results on agroforestry research and practices and stimulate feedback from the scientific community. Other publication series from the World Agroforestry Centre include: Agroforestry Perspectives, Technical Manuals and Occasional Papers.

Published by the World Agroforestry Centre

East and Central Asia Regional Programme

\% Kunming Institute of Botany, Chinese Academy of Science

3/F North Research Building

Heilongtan, 650201 Kunming

Yunnan Province, P.R. China

Tel.: +86-871-6522-3014 - Fax: +86-871-6522-3377

Email: s.vandemoortel@cgiar.org

Internet: www.worldagroforestry.org/eca

(C) World Agroforestry Centre 2015

Working Paper No. 186

Photos: Rob Brooks and Mariusz Kluzniak on Flickr.

\section{Disclaimer and copyright}

The views expressed in this publication are those of the author(s) and not necessarily those of the World Agroforestry Centre. Articles appearing in this publication may be quoted or reproduced without charge, provided the source is acknowledged. All images remain the sole property of their source and may not be used for any purpose without written permission of the source. 


\section{About the authors}

Dr Utkur Djanibekov is a postdoctoral researcher at the Institute for Food and Resource Economics, University of Bonn. Dr Djanibekov is an agricultural and environmental economist, whose research interests include sustainable rural development in developing and transitioning countries, risk management, rural interdependencies and ecosystem services.

Ms Klara Dzhakypbekova is a research fellow at the MSRI/UCA with the Agroforestry Systems of Central Asia Study Team. She worked with the local FAO office on water management, and with the public union Camp Alatoo on pasture degradation. She is currently an MSc candidate at the University of Bonn, focusing on the use of agroforestry to combat land degradation and fodder shortage in Kyrgyzstan.

Dr James Chamberlain is a research scientist with the USDA Forest Service. His professional attention in the last 30 years focused on forestry, forest management, forest products and natural resource issues. He completed his $\mathrm{PhD}$ working on managing forests for non-timber forest products. Dr Chamberlain leads research and technology transfer on forest farming, an agroforestry practice that involves growing non-timber products under forest canopies. He worked on agroforestry and rural development forestry throughout south and Southeast Asia for over 20 years. He is Deputy Coordinator of the Research Group of the International Union of Forestry Research Organizations (IUFRO) that focuses on Non-wood Forest Products.

Dr Horst Weyerhaeuser leads the Mountain Societies Research Institute at the University of Central Asia. He spent nearly 25 years working in Asia in the field of research for development. Earlier, Dr Weyerhaeuser was an advisor to the Lao Ministry of Agriculture and Forestry, responsible for the development and implementation of research programmes and national and regional research strategies. Before that, Dr Weyerhaeuser spent eight years as a senior scientist and country representative in China for the World Agroforestry Centre, where he developed its research strategy, partnership programmes, and the policy support framework for China. Dr Weyerhaeuser received his $\mathrm{PhD}$ in Silviculture Management from Freiburg University.

Prof Dr Robert Zomer is coordinating climatic and hydrological modelling activities throughout the Central Asian region. He is a landscape ecologist, with a broad background in plant community, forest and agricultural ecology, and advanced skills in statistical analysis, geographic information systems (GIS), remote sensing, environmental modelling, and landscape-level spatial analysis. He is currently a visiting Professor at Kunming Institute of Botany and a Senior Landscape Ecologist at the World Agroforestry Centre in East and Central Asia.

Dr Grace B. Villamor is a senior researcher at the Centre for Development Research (ZEF) at the University of Bonn for the West African Service Centre on Climate Change and Adapted Land use Program. Currently, she also works for the World Agroforestry Centre as research fellow. Her research focuses on socio-ecological systems interactions using behavioural experimental games and agentbased models.

Prof Dr Jianchu Xu is an internationally respected leading ethno-ecologist who works in coupled human environmental systems. His current research includes investigation of early warning signals of global change, trans-boundary water governance, landscape restoration, ecosystem services and their resilience, agriculture, and integrative conservation. Dr Xu leads the World Agroforestry Centre's East and Central Asia regional programme. 


\section{Abstract}

This paper discusses how the adoption of agroforestry for ecosystem and livelihood improvement in Central Asian countries can be enhanced. First, it describes how previous and current developments lead to changing environmental conditions, and how these changing conditions consequently affected the welfare of people. Environmental issues on a global level, such as climate change, also threaten people's livelihoods. Using examples from different Central Asian countries, and relying on interdisciplinary methods, the case for agroforestry is made as an option to rehabilitate and create environmental and social resilience. It demonstrates that various agroforestry systems are suitable for various agro-ecological and socio-economic areas in the region. Finally, by identifying current constraints and revealing opportunities, the paper aims to inform and provide recommendations for policy and decision makers and researchers about the potential of applying agroforestry in Central Asia.

\section{Keywords}

Central Asia, Kazakhstan, Kyrgyzstan, Tajikistan, Turkmenistan, Uzbekistan 


\section{Contents}

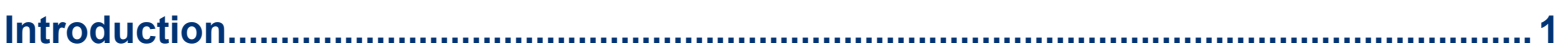

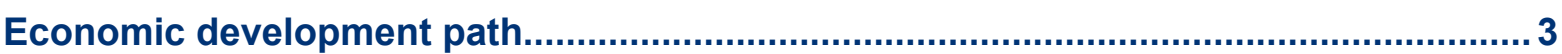

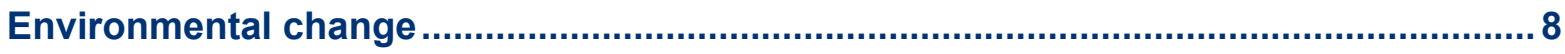

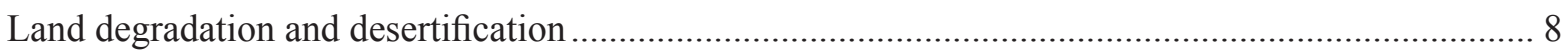

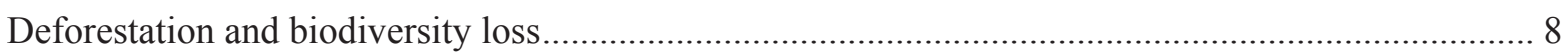

Observed and projected climate change ..................................................................... 12

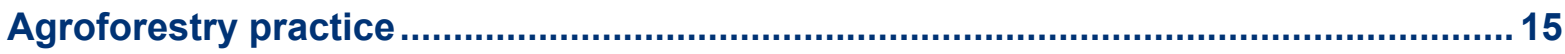

Opportunities for agroforestry development............................................................... 18

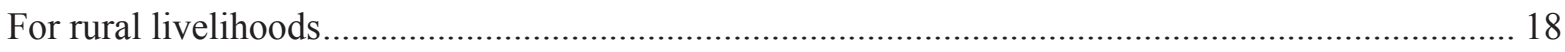

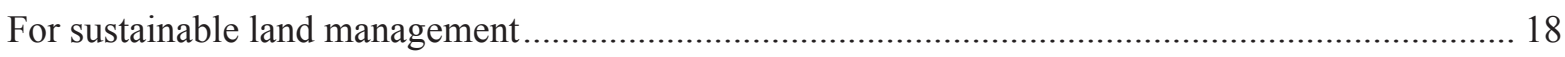

To protect biodiversity and enhance ecosystem services............................................................... 20

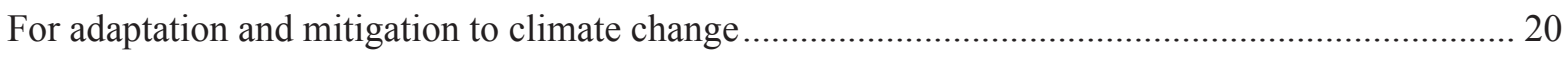

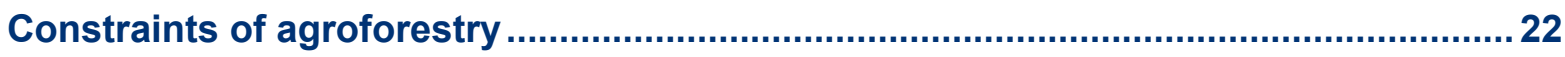

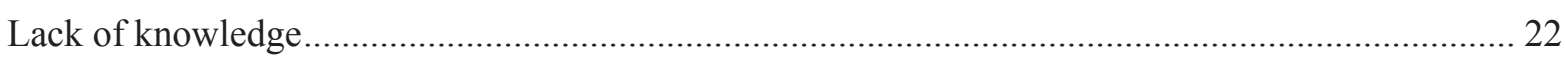

Undeveloped markets and long waiting periods to reap the benefits................................................. 23

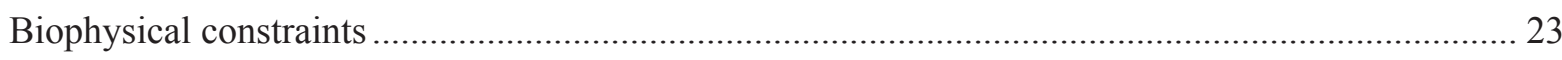

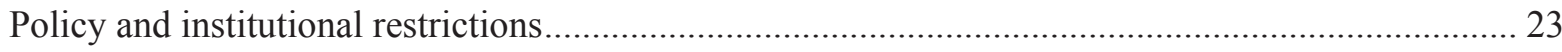

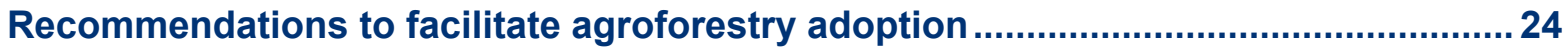

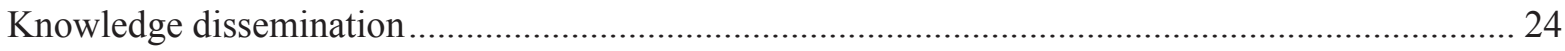

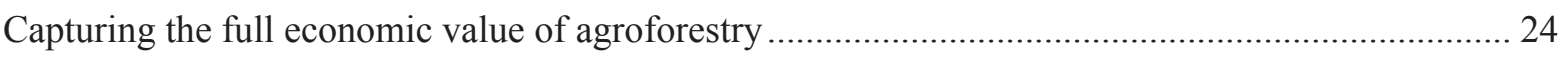

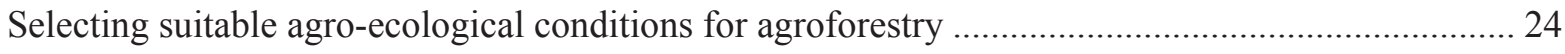

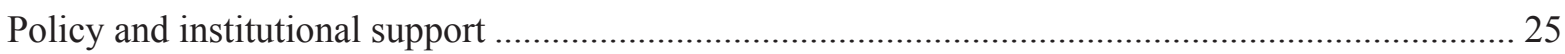

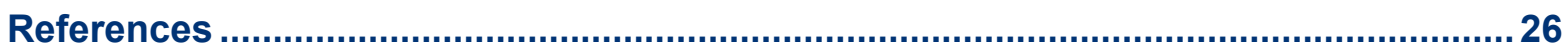





\section{Introduction}

Central Asia consists of five landlocked Asian countries - Kazakhstan, Kyrgyzstan, Tajikistan, Turkmenistan, and Uzbekistan - spanning an area of 4.0 million $\mathrm{km}^{2}$ (Figure 1) and home to over 59 million people. The severe landscape degradation and livelihood uncertainties in the Central Asian Countries (CAC) have been shaped and re-shaped by a series of nation-building processes, centrallydominated government policies and exploitative economy since the mid-1 $9^{\text {th }}$ century when the CAC were under the rule of tsarist Russia. More recently, starting in the beginning of the $20^{\text {th }}$ century (1917), the CAC were part of the Soviet Union, with development policies heavily dominated towards the needs of the centrally planned Soviet economy.

Since their independence in 1991, the CAC economies have been experiencing varying but still relatively rapid transitions towards more market-oriented economies. Despite those socio-economic transformations, the ecological health of the CAC is deteriorating. The Aral Sea is shrinking as the irrigated area of the CAC has increased threefold to support an increase in monoculture production (Saiko and Zonn, 2000). At the same time, a planned increase in the socioeconomic development, agricultural intensification has resulted in further land degradation. In addition, recent projections indicate that in the near to medium term, climate change may impact upon water availability and land productivity, which also affects the biodiversity and ecosystem functioning (Simonett and Novikov, 2010; TEEB, 2011; Malsy et al, 2012; Kaplan et al, 2014; Lioubimtseva, 2014).

Both historical economic and environmental legacies, and the current transition to market-based economies are directly affecting and influencing land use and land use activities, which are of

Figure 1: Map of Central Asian countries.

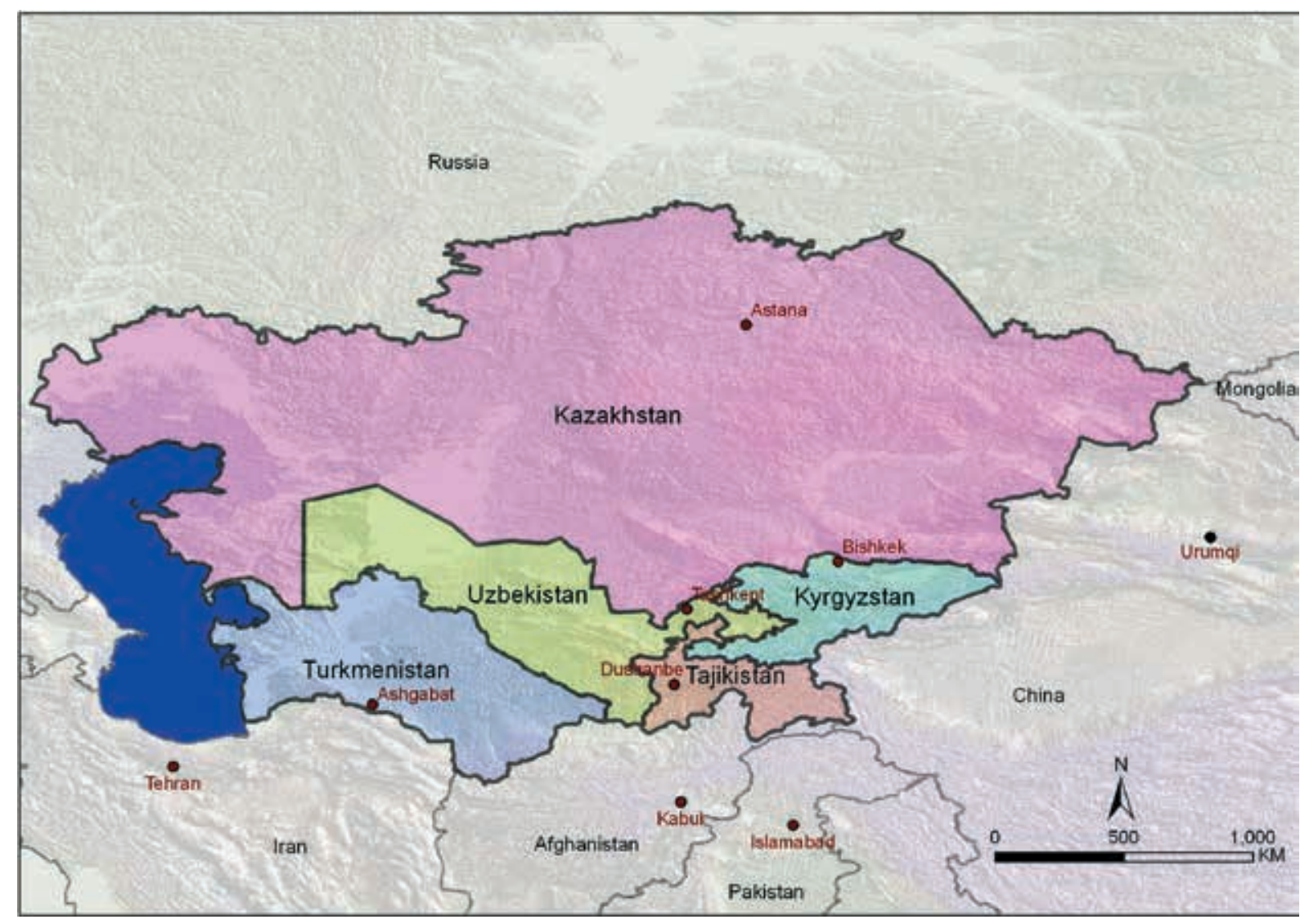


paramount importance in the CAC region and for the welfare of the population. The transition of institutions and infrastructure across the CAC is not yet complete (Lerman, 2009), with each country experiencing varying degrees of difficulty and success in addressing these issues. Much previous research, and some experience from the region, has shown that diversifying farming activities through a variety of agroforestry practices provides options and opportunities to address and ameliorate many of these environmental issues, while increasing livelihoods and providing various high-value and even critical ecosystem services (Messerli, 2002; Khamzina et al, 2012).

At the same time, agroforestry systems and approaches are not well known, or not much accepted by farmers and policy-makers within the region. First, there is some misunderstanding about what agroforestry is, and what is included in various definitions of agroforestry. In general, there is a low priority given to and some lack of awareness and understanding of the range of potential agroforestry approaches available and adapted for the $\mathrm{CAC}$, and the potential benefits of these various agroforestry and multipurpose tree-based systems. Hence, the objectives of this report are to: (1) Provide insights on recent and current socio-economic developments, consequent environmental impacts and feedback effects on the CAC economies; (2) Assess the use of agroforestry practices with the CAC, and the potential for expansion as an option to increase rural livelihoods and address environmental issues; and (3) Identify policy constraints, recommendations and other measures that will improve and provide an enabling environment and will facilitate the adoption of agroforestry practices within the CAC.

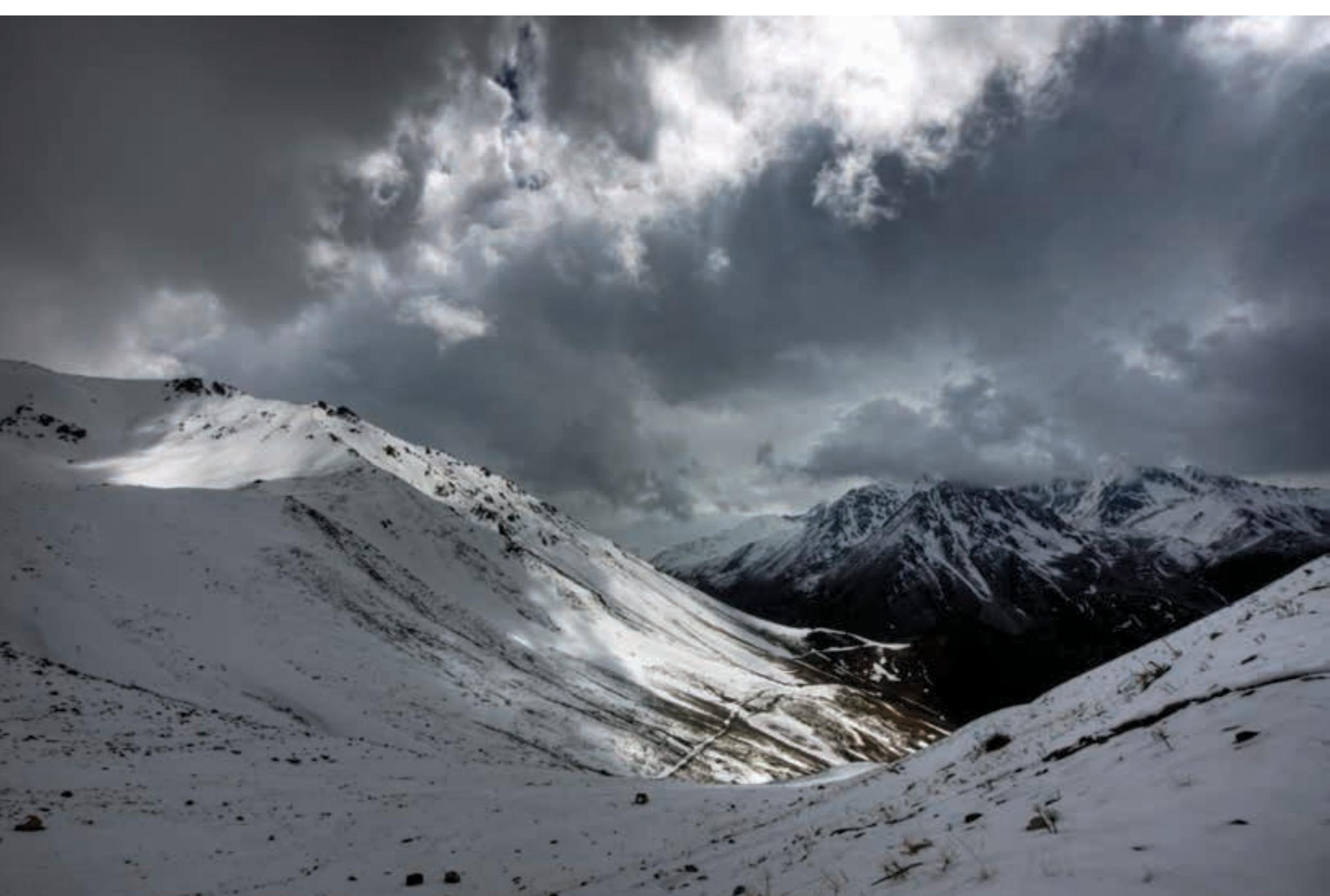




\section{Economic development path}

Central Asia contains a wide variety of steppe vegetation, lake and river systems, alpine mountains and deserts. The Silk Road caravan connected once-thriving ethnic cultural communities and societies over 2000 years ago, enabling interaction between pastoral nomadic (steppe) and sedentary, agricultural societies (sown). The socio-cultural adaptation to grassland and alpine ecosystem involving spatial arrangement of animal, crops, fodders, trees and water constitutes a highly specialized body of knowledge. Mobile herding is an important element of food-producing economies and steppe grassland management. Different groups often dispersed across the diverse agro-ecological zones for food, fodders and water, which resulted in the diversity in subsistence production for more than 2000 years.

The range of subsistence pursuits included mixed small-scale economies with agricultural production and specialized hunting, groups with broad-spectrum hunting-gathering and fishing economies, and still other groups inhabiting fully sedentary villages with developed agriculture such as fruits and nuts orchards and animal husbandry. The traditional steppe cultural emphasis on mobility and the technologies of horse riding and horse-based warfare provided steppe peoples with experience in organizing activities, resources, and peoples over substantial spatial distances. This body of experience facilitated long-distance interactions and exchanges and, most importantly, promoted approaches for effectively managing diverse peoples, languages, and cultures, and control of territory and space. By developing the ability to effectively project their spatial reach, steppe societies already had in place strategies for controlling the logistics and diversity that are characteristic of many largescale imperial polities.

The contemporary development of CAC was significantly shaped by Russian empire and communist Soviet Union. During the tsarist period, the irrigated area was expanded, new crop varieties and management technologies were introduced, and railroads were constructed between main cities and commercial centres of the CAC and Russia (Djanibekov et al, 2010; Spoor, 1993). Due to favourable climatic and geographical settings, the CAC were mainly considered as potential producers of cotton requirements for Russia. In the late 19th and early 20th centuries, about $33 \%$ of the total irrigated areas in CAC was devoted to cotton, mainly cultivated on fertile lands (Djanibekov et al, 2010).

Following the Bolshevik revolution in 1917 in Russia, Central Asia became part of the communist Soviet Union. During this era, the economic policies of CAC were highly centralized and dominated by central authority, both inside and outside the region. The CAC were part of the integrated economy of the USSR and oriented toward the needs of the whole of the Soviet economy, where all infrastructure and institutions were state-owned and linked to the state target production policies. Economic policies were designed in such a way that each country contributed a particular set of commodities, for which they supposedly had comparative advantage, to the whole of the Soviet Union, and at the same time were dependent on other commodities produced by other countries of the Soviet Union. All the input and output prices of the commodities were controlled by the state (Pomfret, 2010).

Among the economic planning in the $\mathrm{CAC}$, the agricultural sector was considered as a backbone of the region, and therefore supported by Soviet policies. The agricultural sector was modernized with the aim of increasing overall agricultural output and arable land area (Glantz, 1999). The region experienced rapid transformation from steppe to cropland (Lioubimtseva and Henebry, 2009), cultivating a substantial area of rain-fed crops, for example large areas of wheat in Kazakhstan. More importantly, the plan of increasing agricultural production was based on increasing the supply of irrigation water to the unexploited areas (Field, 1954). This, in turn, led to a substantial increase in irrigation canals and water withdrawn from the rivers for irrigation purposes. Around the second half of the $20^{\text {th }}$ century, the irrigated areas of the region had almost tripled, and amounted to 7.9 Mha (Saiko and Zonn, 2000), which made it one of the largest irrigation zones in the world. 
Still, cotton was seen as an important crop for the region, notably in Uzbekistan where cotton was cultivated on $61 \%$ of the arable land. The country produced almost two-thirds of Soviet cotton (Djanibekov et al, 2010). Due to the intensification and agricultural developments the crop yields have increased. For example, by the mid-1970s, cotton yields from Uzbekistan amounted to 3 tonnes per hectare, which was the highest among major cotton producing countries (Djanibekov et al, 2010). However, as for many other primary products, the CAC merely supplied cotton fibre for processing by the textile industries of Russia and Eastern Europe (Djanibekov et al, 2010). Hence, the CAC were merely seen as providers of raw materials, primarily cotton, as well as minerals and energy products.

In late 1991, with the collapse of the Soviet Union, the CAC became independent states. Within the common bounds of resource-based economies, the five countries had gradually become more differentiated socio-economically, as their governments introduced various national strategies for transition to a market-based economy. Currently, Kyrgyzstan, Tajikistan and Uzbekistan have levels of output and well-being akin to low-income countries, while Turkmenistan and Kazakhstan exhibit higher levels of GDP per capita (Table 1). With the exception of Kyrgyzstan, the CAC show relatively high levels of GDP growth (above 5\%). The substantially divergent purchasing power parity among the five countries has Kazakhstan ranked with the highest purchasing power, followed by Turkmenistan (although the country has the largest population with an income below $1.25 \mathrm{USD} /$ day). Tajikistan is ranked last.

The CAC range from moderately to highly agrarian societies, with about $40 \%$ of the total population employed in the agricultural sector, accounting for about $17 \%$ of GDP on average across the five countries. The contribution of agriculture varies significantly among countries. For example, the share of agriculture in GDP of Kazakhstan is 5\%, whereas Tajikistan's is 27\%. Despite a dependence on agriculture and fairly high rural population levels, the CAC have relatively little arable land, in contrast to global averages for both low- and high-income countries. This is mainly a result of the aridity and lack of precipitation across most of this region.

Irrigated agriculture is, and has been, the largest consumer of water in the CAC for some time, and provides subsistence to $60 \%$ of the region's inhabitants (Dukhovny and Ziganshina, 2011). Water for irrigation is conveyed from the region's two main rivers, the Amu Darya and Syr Darya, to the main canals, and then through secondary canals and inter-farm canals to the canals at field level (Micklin, 2002). Irrigation and drainage systems are managed by state organizations or public suppliers, e.g. water user associations, the latter being supposed to set water charges to water users via membership fees and payments for services delivered in order to meet the operation and maintenance needs of the system.

Pastureland occupies $30-85 \%$ of agricultural land depending on the country. In Kyrgyzstan, pastureland is the dominant land use occupying about $85 \%$ of agricultural land, highlighting the vital role of livestock production for livelihoods both here, and across in the CAC region more generally ${ }^{1}$. In Tajikistan, agricultural production is mainly practiced within mountainous landscapes. Permanent crops account for less than 1\% (FAO, 2014). Forests are state property in CAC, and make up about $3-10 \%$ of the area, depending on the country.

Since independence from the Soviet Union, there has not been substantial change in land use types. For example, cotton and wheat are still the most important crops in Uzbekistan and Kazakhstan. However, much of the land of the state collective farms (kolkhozes and sovkhozes) has been dismantled and given to individual farms or other land users (Lerman, 2009; Djanibekov et al, 2012a). There are in general three farm types/agricultural producers (Table 2), with the family/private farms occupying the largest portion of the total agricultural area. In Kazakhstan, most of the land is allocated for large-scale grain farming and cattle breeding.

National Environment Report of Kyrgyz Republic for 2006-2011, UNDP/UNEP, 2012, p. 69 
Table 1: Selected development indicators of Central Asian countries and comprison to low and high income countries as the year 2012

\begin{tabular}{|c|c|c|c|c|c|c|c|}
\hline $\begin{array}{l}\text { Development } \\
\text { indicators }\end{array}$ & Kazakhstan & Kyrgyzstan & Takikistan & Turkmenistan & Uzbekistan & $\begin{array}{c}\text { Low } \\
\text { income } \\
\text { countries }\end{array}$ & $\begin{array}{c}\text { High } \\
\text { income } \\
\text { countries } \\
\text { (Euro area) }\end{array}$ \\
\hline $\begin{array}{l}\text { Surface area (1000 } \\
\text { sq.km) }\end{array}$ & $2,724.9$ & 199.9 & 142.6 & 488.1 & 447.4 & $16,197.8$ & $2,693.1$ \\
\hline $\begin{array}{l}\text { Arable land (\% of land } \\
\text { area) }\end{array}$ & 8.5 & 6.7 & 6.1 & 4.1 & 10.2 & $20^{*}$ & 30 \\
\hline $\begin{array}{l}\text { Gross national income, } \\
\text { purchasing power parity } \\
\text { (USD billions) }\end{array}$ & 197.9 & 12.4 & 17.4 & 46.9 & 109.1 & $1,171.1$ & 12,354 \\
\hline $\begin{array}{l}\text { Gross national income, } \\
\text { purchasing power parity } \\
\text { (USD per capita) }\end{array}$ & 11,790 & 2,220 & 2,180 & 9,070 & 3,670 & 1,383 & 37,299 \\
\hline GDP (\% growth) & 5 & -0.9 & 7.5 & 11.1 & 8.2 & 6.3 & -0.6 \\
\hline $\begin{array}{l}\text { GDP (\% per capita } \\
\text { growth) }\end{array}$ & 3.5 & -2.5 & 4.9 & 9.7 & 6.6 & 4 & 0 \\
\hline Agriculture in GDP (\%) & 5 & 20 & 27 & 15 & 19 & 28 & 2 \\
\hline Population (in mln.) & 16.8 & 5.6 & 8 & 5.2 & 29.8 & 846.5 & 331.2 \\
\hline $\begin{array}{l}\text { Rural population (\% of } \\
\text { total population) }\end{array}$ & 46 & 65 & 73 & 51 & 64 & 72 & 24 \\
\hline $\begin{array}{l}\text { Employment in } \\
\text { agriculture (\%) }\end{array}$ & 26 & 35 & 66 & 48 & 29 & 65 & 5 \\
\hline $\begin{array}{l}\text { Population below } 1.25 \\
\text { USD a day ( } \% \text { of total) }\end{array}$ & $<2$ & 6.7 & 14.7 & 63.5 & - & $49.2^{*}$ & 0.5 \\
\hline $\begin{array}{l}\text { Population below } 2 \text { USD } \\
\text { a day ( } \% \text { of total) }\end{array}$ & $<2$ & 22.9 & 37 & 85.7 & - & - & - \\
\hline
\end{tabular}

Note: *Sub-saharan Africa

Source: World Development indicators (2014), eurostat: Agricultural census 2010 http://epp.eurostat.ec.europa.eu.

World Bank Indicators at http://data.worldbank.org/indicator (last accessed 11.10.2014)

Table 2: Agricultural producer categories in Central Asian countries.

\begin{tabular}{|c|c|c|c|c|c|}
\hline Category & Kazakhstan & Kyrgyzstan & Tajikistan & Turkmenistan & Uzbekistan \\
\hline $\begin{array}{l}\text { Farm } \\
\text { enterprises }\end{array}$ & $\begin{array}{l}\text { Agricultural } \\
\text { enterprises }\end{array}$ & $\begin{array}{l}\text { State and } \\
\text { collective farms }\end{array}$ & $\begin{array}{l}\text { Agricultural } \\
\text { enterprises } \\
\text { Includes collective } \\
\text { and state farms, and } \\
\text { cooperatives }\end{array}$ & Peasant associations & $\begin{array}{l}\text { Agricultural } \\
\text { enterprises }\end{array}$ \\
\hline Family farms & $\begin{array}{l}\text { Family farms. } \\
\text { Average } \\
\text { size=309 ha }\end{array}$ & $\begin{array}{l}\text { Family farms. } \\
\text { Average } \\
\text { size=2.8 ha }\end{array}$ & $\begin{array}{l}\text { Family farms. } \\
\text { Average size }=55 \text { ha }\end{array}$ & $\begin{array}{l}\text { Family farms. } \\
\text { Average size }=10 \text { ha }\end{array}$ & $\begin{array}{l}\text { Private farms. } \\
\text { Average } \\
\text { size }=80 \text { ha }\end{array}$ \\
\hline Households & Household plots & Household plots & Household plots & Household plots & Household plots \\
\hline Remarks & $\begin{array}{l}64 \% \text { of farms are } \\
<50 \text { ha, operate } \\
2 \% \text { of land. }\end{array}$ & $\begin{array}{l}\text { Arable land is } \\
\text { mostly distributed } \\
\text { equally to rural } \\
\text { families. }\end{array}$ & $\begin{array}{l}80 \% \text { of farms are } \\
<10 \text { ha. }\end{array}$ & $\begin{array}{l}\text { Farmers associations } \\
\text { operate } 94 \% \text { of } \\
\text { arable land; family } \\
\text { farms about } 1 \% \text { of } \\
\text { land. }\end{array}$ & $\begin{array}{l}54 \% \text { of farms } \\
\text { in cotton-wheat } \\
\text { (average size = } \\
106 \text { ha), } 31 \% \text { in } \\
\text { vegetable and } \\
\text { fruit (average } \\
\text { size = } 15 \text { ha) }\end{array}$ \\
\hline
\end{tabular}

Sources: AGRIWANET project (2014), Djanibekov and Wolz (2015). 
In contrast, the farm areas in Kyrgyzstan, Tajikistan, Turkmenistan and Uzbekistan are relatively smaller. Within the countries, farm sizes differ substantially depending on their geographic location and production specialization. The majority of households in the rural areas across the region have access to a small plot (0.08-0.3 ha) of land, usually attached to homes. Kitchen gardens are a household asset and play an important role in food security, providing a source of food and income as part of the produce from the household plots is supplied to the local markets. Since the collapse of the Soviet Union, some cropland has been abandoned by farmers (IUCN, 2010). According to Chen et al (2013), farmland area in the CAC has been reduced by $32 \%$ (as of 2009) when compared to 1990.

This transition from a centrally-planned and highly subsidized agricultural sector towards a more market based economy is proceeding at varying and various rates across the region, but in general is not yet fully developed. Some of the previous Soviet-era institutions remained or evolved, while others declined or disappeared (Brück et al, 2013). The previous investments into the institutions, infrastructure, factories and management practices were high. The structural change associated with reorganization or diversification of the agricultural sector may require significant investments and result in high costs. Some CAC continue to experience economic difficulties in adjusting policies, institutions and infrastructure to meet domestic demand, a legacy of previous agro-economic policy which viewed the region as a single unit of the larger Soviet economy, and planned accordingly. For instance, despite a relatively high share for agricultural production in national GDP, Kyrgyzstan does not produce sufficient food and is dependent on imports (FAO, 2012). This has led to decreased consumption of some food groups to levels lower than required (Nurgaziev et al, 2013).

At regional level, there is no consensus about water distribution among the CAC. The overriding issue is that the upstream countries (i.e. Kyrgyzstan and Tajikistan) of the two major rivers, the Syr-Darya and the Amu-Darya, to power their countries, are aiming to expand the construction of upstream hydropower dams. This may reduce river water runoff and affect the livelihoods of rural population that are highly dependent on the irrigated agricultural production found in the downstream areas (i.e. Turkmenistan, Uzbekistan, and southern regions of Kazakhstan) (Eshchanov et al, 2011). 

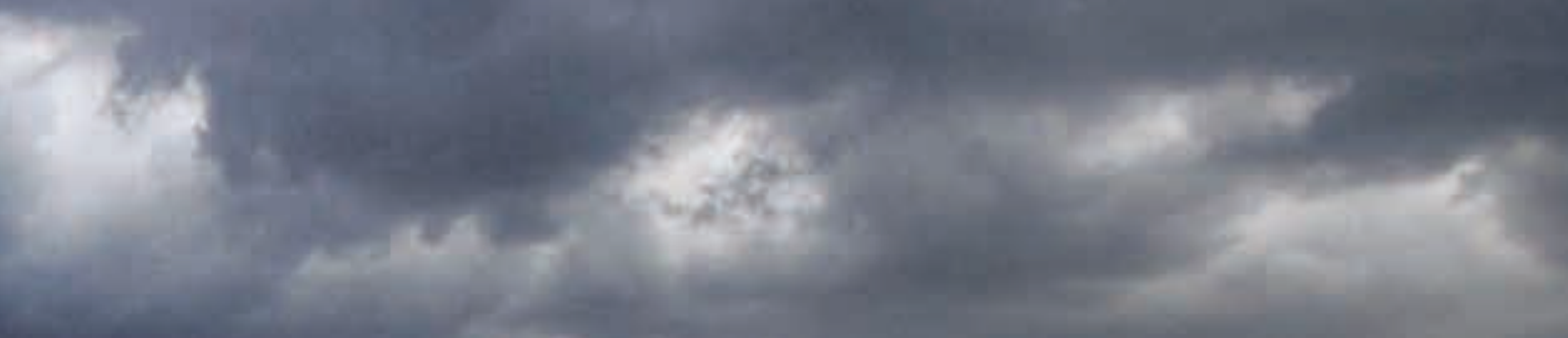

$x^{2}$

$-$ semets
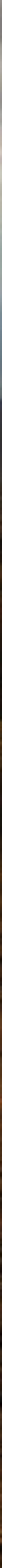


\section{Environmental change}

\section{Land degradation and desertification}

The development policies in the CAC and the legacy of past policies have impacted upon, and are affected by, several major environmental issues. The rapid and sometimes drastic economic developments, and especially the expansion of agricultural production in the region, relied on intensive use of inputs, often subsidized by the state. Such intensification and other ill-advised farming and land use practices have resulted in widespread land degradation, with approximately $30 \%$ of cropland area considered marginal (El Beltagy, 2002), and this process of degradation continues (O’Hara, 1998; Pender et al, 2009; Dubovyk et al, 2013). The major types of land degradation prevalent in the region notably include soil erosion in the rain-fed and mountainous areas, secondary salinization in the irrigated lands, and desertification or reduced vegetation across a range of land cover and land use types (Gupta et al, 2009). Intensive grazing and lack of management of highaltitude and steppe/desert pastures has led to significant and widespread degradation over the last few decades. The annual costs of land degradation are estimated to be about 2 billion USD for the region (World Bank 1998, ADB 2004). These estimates are considered moderate, since it was also reported that Uzbekistan alone loses about 1 billion USD annually (World Bank, 2007). The costs of desertification are estimated to be about $3 \%$ of total income of CAC (Suzuki, 2003).

Use of river water for agricultural production in downstream countries and water use for hydropower generation in the upstream countries has significantly reduced downstream river discharges, in many cases beyond the lower limits to maintain sustainable environmental flows, and has led to the desiccation of the Aral Sea. According to recent satellite images of the National Aeronautics and Space Administration ${ }^{2}$, the largest section of the lake (eastern basin) has now completely dried up. These in turn impact upon rural livelihoods, incomes and food diets, and result in decrease of job opportunities (e.g. due to cease of fish production), health issues in the local community, and land degradation due to dust storms (Micklin, 2010).

\section{Deforestation and biodiversity loss}

Deforestation is another form of land degradation that is present and a major issue in all CAC (Kleine et al, 2009), which also implies a loss of habit and biodiversity. Forests have been mainly deteriorating due to increased anthropogenic pressures and the breakdown of an effective forest management system after independence (Fisher et al, 2004). About $30 \%$ of the rural population lives near forests and depends directly on forest products. However, it should be noted that tree cover within the CAC is overall quite low (Figure 2), particularly when compared to more humid regions (Eastwood et al, 2009), but even when compared to other arid regions of the world (Zomer et al, 2009; 2014). An analysis from 2006 shows that Tajikistan has the least forest cover, with around 3.9\% of its total land area covered by forest or woodland, whilst Uzbekistan has the most, with $10.1 \%$ of its land wooded (FAO, 2006a). Kyrgyzstan, Kazakhstan and Turkmenistan have 6.2\%, 7\% and 8.8\% forest and woodland cover respectively. However, a large proportion of woodland in Kazakhstan and Turkmenistan is composed of desert saxaul Haloxylon spp. shrublands (FAO, 2006). This is highlighted using data from a recent analysis by Hansen et al (2014) to tabulate tree cover (i.e. all vegetation above $5 \mathrm{~m}$ in height) in the year 2000, which shows that of the five CAC, only Kyrgyzstan (with 5.0\%) and Kazakhstan (with 2.2\%) have a tree cover of greater than $10 \%$ over more than $2 \%$ of their total area (see Table 3).

\footnotetext{
2 http://www.nasa.gov/topics/earth/features/fluxGallery/Aral_Sea.html
} 
Figure 2: Tree cover in the Central Asian countries in the year 2000

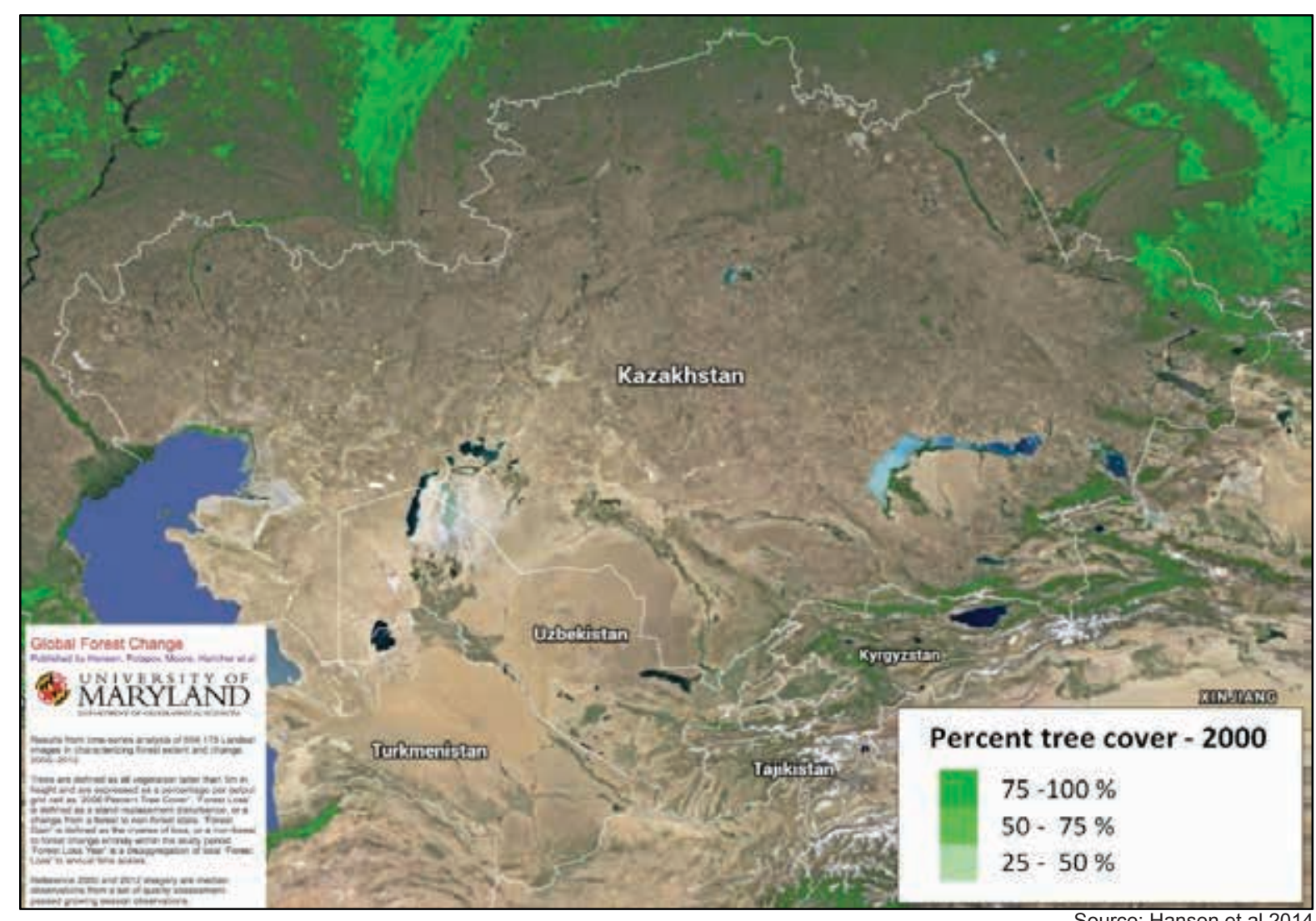

Source: Hansen et al 2014

Table 3: Tree cover in Central Asia

\begin{tabular}{|c|c|c|c|c|c|c|c|}
\hline \multirow{3}{*}{ Country } & \multirow{3}{*}{$\frac{\text { Total Area }}{\mathbf{k m}^{2}}$} & \multicolumn{6}{|c|}{ Tree Cover 2000} \\
\hline & & \multicolumn{2}{|c|}{$>10$} & \multicolumn{2}{|c|}{$>20$} & \multicolumn{2}{|c|}{$>30$} \\
\hline & & $\mathrm{km}^{2}$ & $\%$ & $\mathrm{~km}^{2}$ & $\%$ & $\mathbf{k m}^{2}$ & $\%$ \\
\hline Kazakhstan & $2,722,404$ & 58,843 & 2.2 & 48,210 & 1.8 & 42,262 & 1.6 \\
\hline Kyrgyzstan & 199,248 & 10,029 & 5.0 & 7,923 & 4.0 & 6,742 & 3.4 \\
\hline Takikistan & 141,885 & 1,726 & 1.2 & 993 & 0.7 & 602 & 0.4 \\
\hline Turkmenistan & 489,168 & 315 & 0.1 & 146 & 0.0 & 102 & 0.0 \\
\hline Uzbekistan & 446,442 & 2,550 & 0.6 & 1,554 & 0.3 & 1,058 & 0.2 \\
\hline Central Asia - All & $3,999,148$ & 73,463 & 1.8 & 58,826 & 1.5 & 50,767 & 1.3 \\
\hline \multirow[t]{2}{*}{ Country } & \multicolumn{2}{|c|}{ Tree cover $>10 \%-2000$} & \multicolumn{2}{|c|}{$\begin{array}{r}\text { Tree cover }>10 \%- \\
2012\end{array}$} & Tree gain & Tree loss & Net Gain/loss \\
\hline & $\left(\mathrm{km}^{2}\right)$ & $\%$ & $\left(\mathrm{~km}^{2}\right)$ & $\%$ & $\left(\mathrm{~km}^{2}\right)$ & $\left(\mathrm{km}^{2}\right)$ & $\left(\mathrm{km}^{2}\right)$ \\
\hline Kazakhstan & 58,843 & 2.2 & 58,257 & 2.1 & 239 & 825 & -586 \\
\hline Kyrgyzstan & 10,029 & 5.0 & 9,999 & 5.0 & 5 & 35 & -30 \\
\hline Takikistan & 1,726 & 1.2 & 1,720 & 1.2 & 1 & 7 & -6 \\
\hline Turkmenistan & 315 & 0.1 & 311 & 0.1 & 3 & 7 & -4 \\
\hline Uzbekistan & 2,550 & 0.6 & 2,540 & 0.6 & 5 & 15 & -10 \\
\hline Central Asia - All & 73,463 & 1.8 & 72,827 & 1.8 & 253 & 889 & -636 \\
\hline
\end{tabular}


Large-scale destruction of formerly abundant mountain forests in Central Asia began in the early Middle Ages with the growth of mining and metallurgy (Alibekov, 2000), and continued well into the second half of the twentieth-century, with a particularly intensive period from 1860-90 due to industrialization. Walnut and fruit-tree forests have disappeared from about 10 million hectares during the last century. Degradation of remaining forests continues. For example, juniper forests in Uzbekistan, which now account for 52\% of the remaining forest there, continue to be threatened. Dense pistachio and almond forests formerly found in this region are now almost completely gone.

Despite the current low forest cover across Central Asia, the people of the region nevertheless have a historically strong association with and dependency on forests to provide firewood, timber and food (nuts, fruit, mushrooms and honey). For example, the name of Kazakhstan's former capital, Almaty, literally means 'the Father of Apples'. Currently, wood fuel is still important and much in use in Kyrgyzstan and Tajikistan where a high proportion of the population live in rural areas and do not have access to fossil fuels. In Tajikistan more than $80 \%$ of rural households rely on fuelwood as the main source of cooking energy (FAO, 2006a). Since the independence, all CAC - apart from Turkmenistan - have seen an increase in the demand for fuelwood (FAO, 2006a).

Forest plantations, generally of low productivity, make up only a small proportion of the total forest cover in Central Asia, and are mainly set aside for protective measures rather than for wood production. Most CAC depend on imported wood, although imports have drastically reduced since the break-up of the Soviet Union (FAO, 2006a). Although logging is officially illegal in the majority of the indigenous forests in Central Asia, substantial quantities are still removed (FAO, 2006a). Trees are felled for timber and, in the case of walnut, to produce veneer for furniture. The amount of illegal felling that is currently taking place is not known (Eastman et al, 2009).

Although located primarily in the mountainous portions of the CAC region, forests continue to play a pivotal role in community livelihoods and regional environmental protection, providing an array of ecosystem services, preventing soil erosion and desertification, and regulating watersheds. A diverse range of forest and woodland types, some unique to the region, are associated with the diverse array of bio-climatic conditions to be found across the Central Asian region. The region supports a rich biodiversity, with some 8300 species of vascular plants (Kamelin, 2002) of which approximately $10 \%$ are thought to be endemic. The mountains of Central Asia are a recognized global biodiversity hotspot, supporting over 300 wild fruit and nut species. These include wild species of apple (four species), almond (8-10 species), cherry (8-10 species), plum (4-5 species), and walnut (one species) as well as many domesticated varieties.

The Russian geneticist and plant breeder N.I. Vavilov stated that the region was one of the world's eight centres of crop origin and domestication (Hawkes, 1998) due to its rich diversity of fruit and nut species. For example, recent molecular genetic studies strongly support the hypothesis that the domestic apple originated from Kazakhstan (Harris et al, 2002). Altogether it is estimate that there are 500-600 arborescent species in Central Asia, of which 100-150 can be classified as trees, the remainder being shrubs (Eastman et al, 2009). This includes taiga species such as Abies sibirica and Picea schrenkiana as well as desert shrubs such as Haloxylon persicum and H. aphyllum. High species diversity and endemism is particularly notable in the shrubby genera Calligonum, Tamarix, Astragalus, Cotoneaster, Rosa and Crataegus.

The Global Forest Resources Assessment 2005 (FAO, 2006b) indicates that the extent of forests and woodlands in Central Asia has remained relatively unchanged since 1995. However, the reliability of the data provided for the assessment is uncertain owing to the region's lack of capacity to monitor and conduct forest inventories since the break-up of the Soviet Union. Hansen et al's (2014) remotesensing-based analysis shows that the region had a net loss over the last decade (2000 to 2012) in tree cover (i.e. vegetation cover $>5 \mathrm{~m}$ in height) of a little over $600 \mathrm{~km}^{2}$, which, considering the size 
of the CAC region, is negligible.

There is very little official information on the actual status of forests, their associated species and levels of degradation (Eastman et al, 2009). However, various reports, national biodiversity strategies and the experience of regional experts (MEP, 1998; MNPT, 2002; Safarov, 2003; Cornet and Rajapbaev, 2004; IRIN, 2003) all indicate that Central Asian forests and woodlands are under severe threat from over-exploitation, desertification, pests and diseases, over-grazing and fires. A combination of factors including the cessation of subsidized timber from the former Soviet Union, rural poverty, a lack of alternative energy sources and the lack of institutional capacity to protect and regulate forests have all added to the pressure on vulnerable forests of the region (Eastman et al, 2009).

The forests and woodlands growing on the foothills of the Tian Shan,

Pamir-Altai and Kopetdag mountains, especially those near rural settlements,

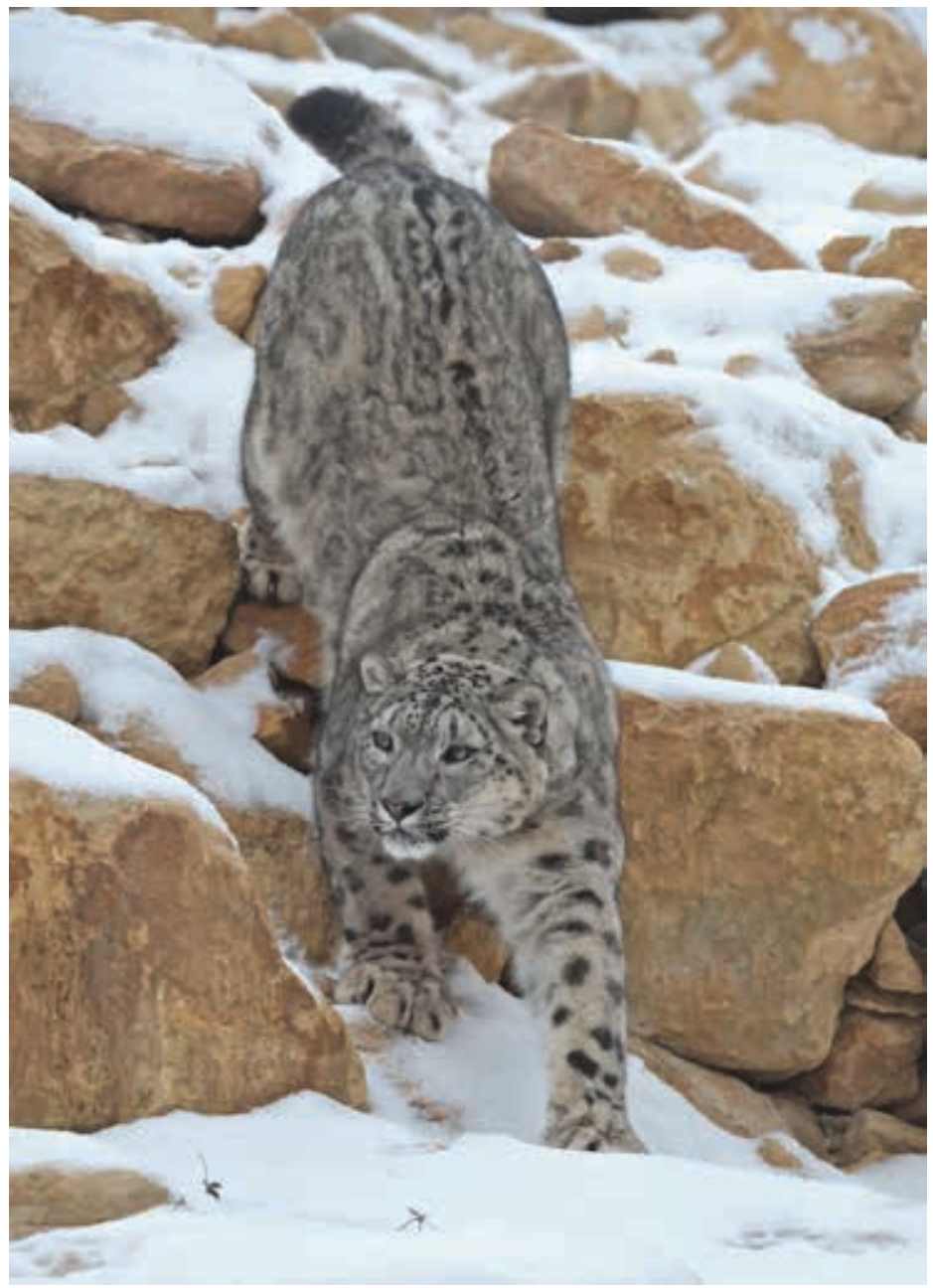
are most threatened. This includes the slow-growing juniper forests of Tajikistan and Kyrgyzstan, which are threatened by firewood collection and over-grazing. Kyrgyzstan, for example, lost some $35 \%$ of its montane juniper in just a few decades (MEP, 1998). As firewood becomes increasingly scarce around settlements, villagers have to go further and deeper into the forest to satisfy their daily fuel needs. Likewise, although an important source of income for local communities, unsustainable harvesting of non-timber forest products such as walnuts, or wild crafted medicinal plants for export, poses a major threat to the conservation of the region's unique fruit and nut forests. A report by Conservation International (CI, 2008) on biodiversity hotspots estimates that some $90 \%$ of fruit and nut forest habitats have been lost across the region in the last 50 years.

Vital environmental protection and ecosystems services are provided by the forests of the relatively wet Tian Shan and Pamir-Altai mountains, as well as the floodplain tugai forests. Their loss and degradation not only threatens globally unique biodiversity and rural livelihoods but also endangers water supply and regulation, essential to fertile downstream irrigated agricultural areas such as the Fergana Valley and the major cities of the region. An assessment of conservation status of Central Asian trees (Eastwood et al, 2009) found that of 96 taxa evaluated, 44 were either Critically Endangered, Endangered, or Threatened, with a further five taxa Near Threatened. A significant proportion of these are wild relatives of globally important fruit and nut crops. Moreover, biodiversity is also substantially impacted by the desiccation of the Aral Sea. This can be illustrated by the decrease in surface areas, from 550,000 ha to less than 30,000 ha, of the deltaic zone, which was a habitat for many animals, fish and plants (TEEB, 2011). 


\section{Observed and projected climate change}

Central Asia has a distinctive continental arid and semi-arid climate with hot, cloudless, dry summers and moist, relatively warm winters in the south and cold winters with severe frosts in the north.

Precipitation throughout most of the region has a spring maximum with high variation. Western and central Pamir regions and the western Tian Shan receive the bulk of precipitation during winter and spring seasons. Eastern Pamir and northern Tian Shan have spring-summer maximum precipitation.

Palaeoclimatic and archaeological data indicate that the climate of Central Asia has experienced many past fluctuations that might be comparable with future climate change. Meteorological data series available since the end of the $19^{\text {th }}$ century show a steady increase of annual and winter temperatures in this region. In Tian Shan Mountain, the average temperature trend has increased $0.2^{\circ} \mathrm{C}$ per decade since 1950, with winter temperatures rising most strongly (Siegfried et al, 2011).

Figure 3: Mean annual temperature across the Central Asian countries, showing current conditions (2000), based on spatially interpolated weather station data, averaged from 1960-2000, and as projected for the year 2050 under the RCP 4.5 and RCP 8.5 emission scenarios.
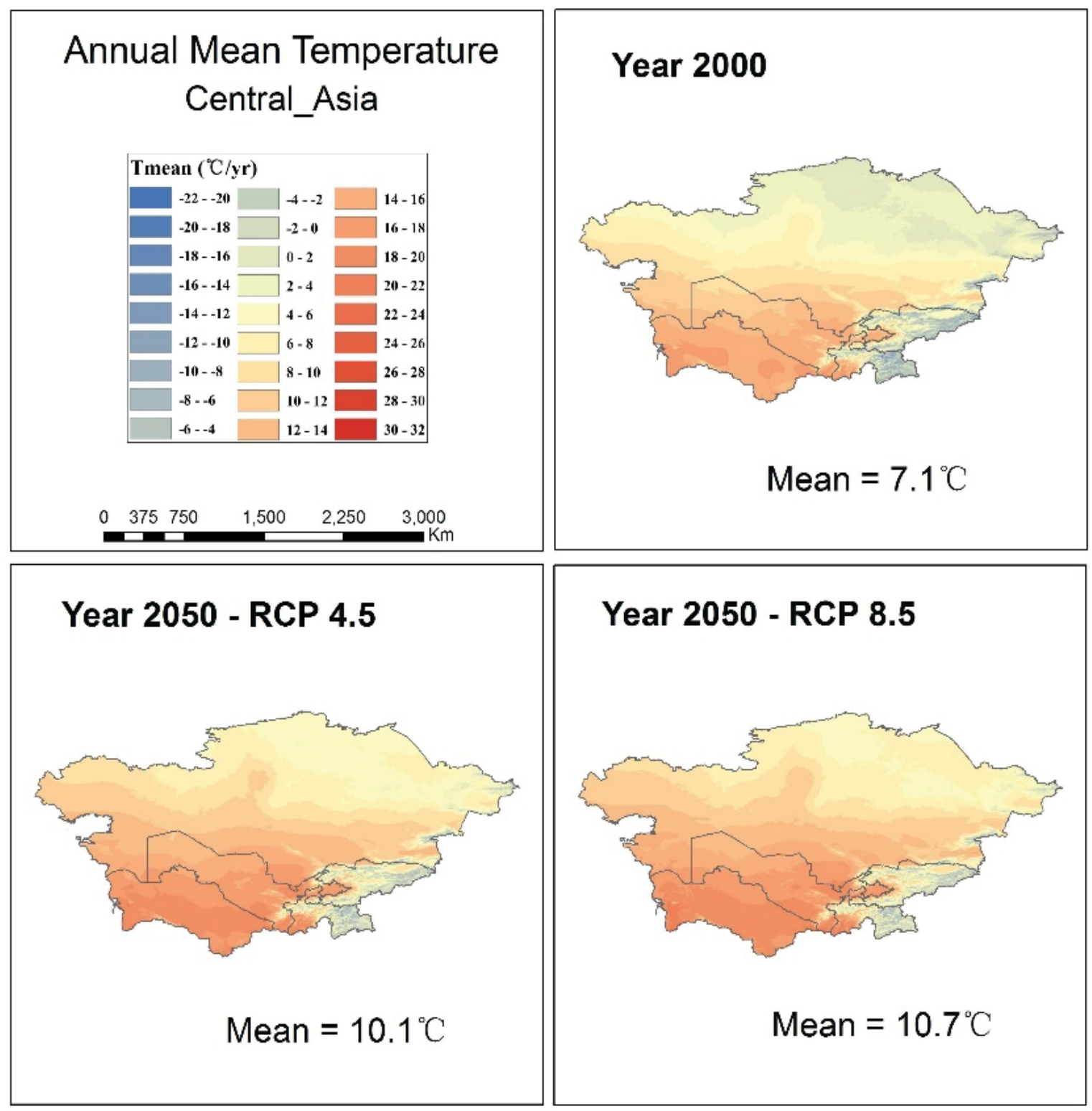

Source: Zomer et al (2015) 
Trends for anticipated and modelled climate change across the CAC indicate that the magnitude of these effects will have substantial impact on land cover, land use, and agricultural output. According to Lioubimtseva et al (2005), it is expected to experience temperature increases of $1-2^{\circ} \mathrm{C}$. In a more recent analysis based on a multi-model ensemble approach using 19 CIMP5 Earth System Models across the four IPCC AR5 emission scenarios (Resource Conservation Pathways, or RCP), Zomer et al (2015) estimate that, by 2050, mean annual temperatures for these five countries are projected to increase by $2.0^{\circ} \mathrm{C}$ to $3.6^{\circ} \mathrm{C}$ on average across the four emission scenarios (Figure 3). Kazakhstan shows the largest increase in temperature in the region (Figure 4). For the region overall, the average mean annual temperature of $7.1^{\circ} \mathrm{C}$ is projected to rise on average $3.0^{\circ} \mathrm{C}$, with the range of projections across the emission scenarios ranging from 2.5 to $3.6^{\circ} \mathrm{C}$.

These projected effects of climate change, particularly if they include reduced precipitation or increased water scarcity due to increased potential evapotranspiration, could affect crop yields (due to change in temperature and precipitation) and thereby impact food security and rural incomes (Bobojonov and Aw-Hassan, 2014). According to Mirzabaev (2013), the aggregate impacts of climate change on CAC agriculture would range between -1.43 to $+1.21 \%$, which in monetary values would range between -210 to +180 million USD (relative to 2010 levels) of net crop production revenues by 2040 . With only $1{ }^{\circ} \mathrm{C}$ increase in temperature, the demand for agricultural irrigation in the arid and semi-arid regions of CAC, due to increased potential evapotranspiration, is estimated to grow by at least $10 \%$ (Fischer et al, 2007). Deteriorating irrigation and drainage systems add to the increased agricultural water use in the downstream areas of CAC (Bucknall et al, 2003).Perelet (2007) projected that the availability of water in the two main rivers of the CAC - the Amu Darya and Syr Darya - will be reduced due to climate change impacts.

Figure 4: Mean annual temperature across the Central Asian countries, showing current conditions (2000), based on spatially interpolated weather station data, averaged from 1960-2000, and as projected for the year 2050 under the RCP 4.5 and RCP 8.5 emission scenarios

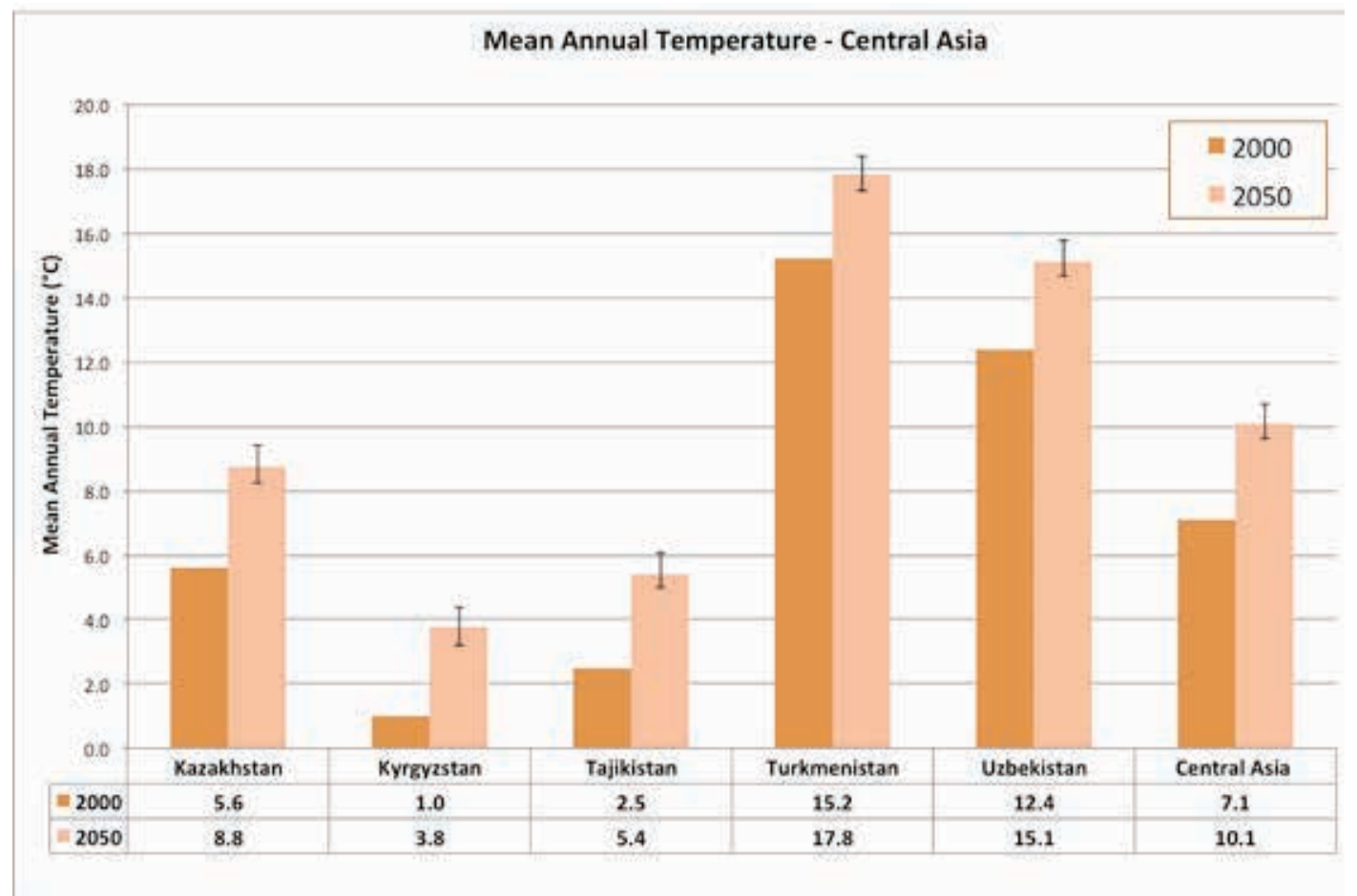


There are significant implications of these projected levels of climatic change for the distribution and shifting of bioclimatic conditions across the region, and the impact on terrestrial ecosystems, spatial distribution of vegetation types, habitat, and growing conditions, and biodiversity (Zomer et al, 2015). For example, the lower limit of fir trees in the Tian Shan has shifted $100 \mathrm{~m}$ to $200 \mathrm{~m}$ higher (Alibekov, 2000). The former mountain forests are now replaced by sedge-meadow grass formations.

Over the last decades, the frequency of droughts have increased and was particularly acute in the downstream regions (i.e. Kazakhstan, Turkmenistan and Uzbekistan) (Dukhovny and Ziganshina, 2011). Severe droughts in the region in 2000-2001 reduced incomes of rural population, with a recovery period of five years for household economies to return to normal levels (Dukhovny and Ziganshina, 2011). To date, the downstream areas of the CAC have increased agricultural water demand (contributing only $14 \%$ to total river runoff, but withdrawing $83 \%$ ). In the future, there is the possibility that the quantity of irrigation water supply may decrease due to construction of dams in upstream countries, notably Kyrgyzstan and Tajikistan (which contribute $80 \%$ to total river runoff and consume only 16\%) (Micklin, 2007).

Both the current and future variability of the climate and irrigation water supply contributes to year-to-year uncertainty concerning crop output in the CAC (Bobojonov and Aw-Hassan, 2014). In addition, combined with this uncertainty of crop productivity, weak markets and undeveloped risk management options have led to high price fluctuations, which increase uncertainty regarding profitability of land use. The lack of risk management options (insurance mechanisms, storage facilities) in the region can be explained due to the undeveloped infrastructure and transition policies (Velandia et al, 2009).

Figure 5: Poplar plantation on a sloped plot Barskoon village, Kyrgyzstan. (b) Poplar plantation for waterlogged land drainage purpose, Issik-Kul, Kyrgyzstan

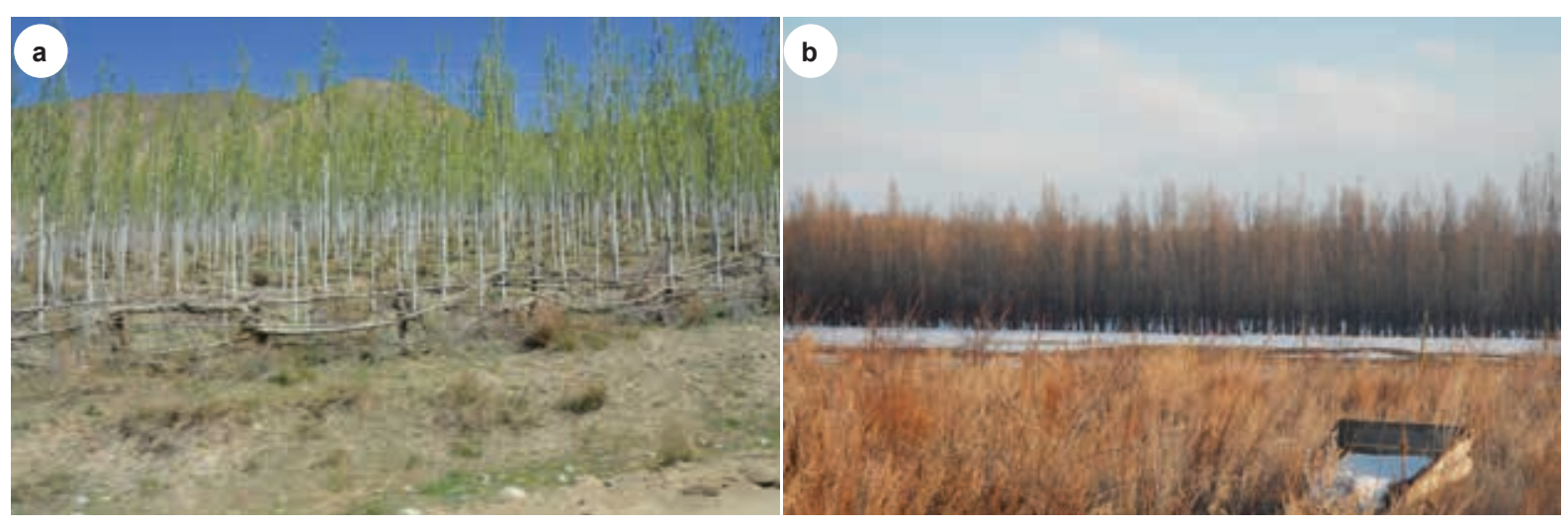

Source: (a) Chamberlain, (2014); (b) Dzhakypbekova, (2014) 


\section{Agroforestry practice}

Agroforestry is the sustainable integration of trees with food crops and livestock on the same unit of land. It can be important in avoiding land degradation. Some pioneer tree species can grow in extreme environmental conditions such as saline soil and drought environment. Trees tend to prevent erosion, replenish soil nutrition and fertility, and improve microclimates including soil moisture. Farmers in Central Asia are famous for using different fruit-and-nut based agroforestry systems.

Despite all benefits from agroforestry system, agroforestry was not considered at Central Asia governmental agenda during Soviet Era due to the secluded nature of the countries, and the limited access to the international research community (Messerli and Yuldashev, 2000). Although not described as agroforestry, soviet researches proposed various methods to increase agricultural production by multifunctional farming. First studies close to agroforestry were mostly related to forestry studies. In the 1930s the Russian scientific expeditions sent to assess forest resources of Kyrgyzstan proposed number of recommendations for further development of local forestry, among them scientists proposed the cultivation of wild fruit species in order to increase fruit productivity of wild species. It was called forest gardening (Popov et al, 1935; Gusev, 1938; Prutensky, 1962). From this point of view, agroforestry can offer multi-purpose tree plantations providing a combination of wild species, fruit or nut trees and multi-purpose trees improved by grafting or pruning, that could ensure beneficial multi-side effects both for conservation and for the society (e.g. walnut and wildfruit trees in Jalal-Abad Oblast).

Nowadays, different types of agroforestry practices are introduced for landscape restoration and livelihood development in CAC. Some of the major agroforestry type practices found within the CAC, each with associated benefits and functions, are listed below:

a. Managed woodland for non-timber forest products: in southern Kyrgyzstan, farmers have traditional to harvest walnuts and hay from native walnut-fruit forests. A recent study by Rehnus et al (2013) highlights importance of walnut production for farmer income and hay-making for wintering of livestock. Other fruits, nuts, berries, mushrooms and medicinal herbs are also collected in large amounts throughout the region. Gathering of firewood is probably the main nontimber forest products provided by the walnut forests (Messerli, 2002), as well as other forests and shrublands throughout the region;

b. Silvopasture: Silvopasture combines trees and livestock, which could involve planting of fodder trees, tree-based understory fodder production-hay-making, and/or grazing and cover-crops for orchard floor management. Forest grazing, which is similar, consists of grazing of animals under the forest canopy.

c. Windbreaks are wide spaced, single and multiple rows of trees in agricultural fields that help to mitigate the impact of excessive wind, and ameliorate other issues such as drainage or soil erosion (Figure 5). Such land use option is usually practiced by family farmers. Various windbreak systems using sever different tree species are evident in farm fields across the CAC (Messerli and Yuldashev, 2000). Windbreaks can increase in crop yields by $10-20 \%$ in Uzbekistan (Tupitsa et al, 2006). Bulichev and Onischenko (1979) documented the erosion control and water saving effects of windbreaks in Chuy Oblast of Kyrgyzstan. In their study the windbreaks included combinations of different trees, such as apricots, pendent white birch, elm, white willow, green ash, black poplar, English oak, mulberry, sugar maple, and apple trees. With windbreaks, winter wheat production increased by $14-28 \%$, maize increased by $17-40 \%$, and sugar beet by $7-17 \%$.

d. Fruit-based agroforestry: intercropping fruit trees with crops in home gardens and across the farm landscape is widespread throughout Central Asia, especially in households but also by horticulture family farms (Figure 6). Such gardens mostly are planted to ensure fruit production for the 
Figure 6: Combination of vegetable/ fodder clover production with cherry/peach, poplar and walnut plantations on a low fertile stony land plot, Aral village, Kyrgyzstan.
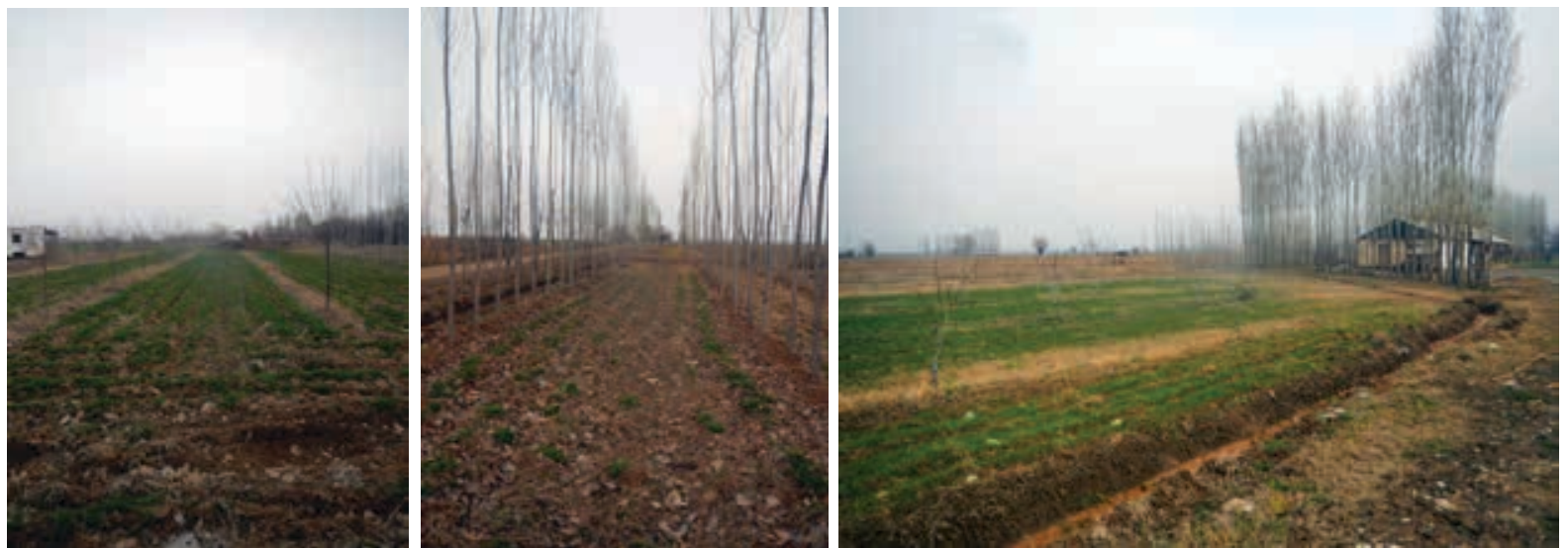

Source: Dzhakypbekova (2014)

Figure 7: (a) Alley cropping on the household land: apple trees with raspberry bushes. (b) A woman running the kitchen garden with pomegranates
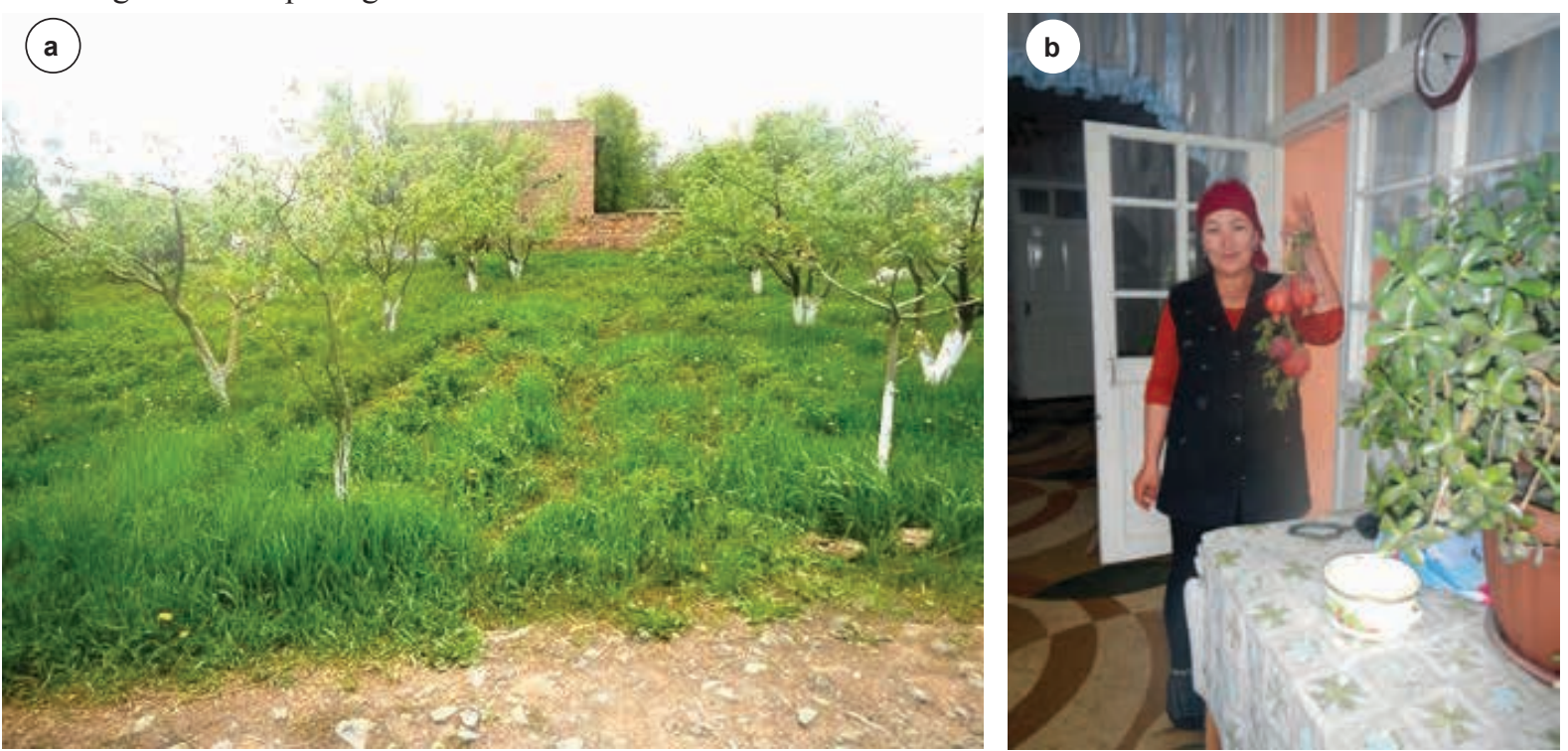

Source: Dzhakypbekova, (2014). 
family food consumptions, and as a source of additional income. Intercropping of wheat or other understory crops in existing orchards is often found in CAC. Kan et al (2008) found that almost all farmers in Khorezm, Uzbekistan intercropped fruit trees with annual crops. Apricot trees are often found combined with cotton, vegetables, legumes, melons and annual herbs;

e. Alley cropping focuses on the growing of crops in-between rows of trees. This can be done on flat land, with nitrogen fixing trees for example, or on steep hillsides to prevent soil erosion, and is similar to both wind-breaks (usually closer spacing), and intercropping of fruit trees in orchards. Afforestation of mountain slopes in Tajikistan with apple trees tolerating rain-fed conditions, and combining with rain-fed wheat production provided higher yields, richer diversity of crops and protection of slopes from wind erosion, increasing both household and community socioecological resilience. Some alley crops can serve as green manure (e.g. peas, lentil, flax). In addition, alley cropping is practiced by the silk producing farmers in Uzbekistan. Where such farmers between the mulberry plantations (used as feed for silk worms) plant wheat;

f. Riparian buffers are planted along streams and rivers to protect the banks from erosion and to slow the movement of nutrients from farm fields into the water system, as well as providing wildlife habitat and biodiversity conservation benefits;

g. Kitchen gardens are crucial for farm households, and vulnerable populations, such as retired farmers or women, for producing small amounts of fruits, berries, vegetables and fodder to sustain household nutrition and food security, and obtain wood fuel for the winter season (Figure 7). During the early development of home gardens in Kyrgyzstan, inter-cropping with potatoes, beets, carrots, cabbage, tomatoes, and wild strawberry is viable agroforestry (Turgunbaev et al, 2012);

h. On-farm woodlots and (community-based) timber production provides wood, timber and other useful resources locally, as well as diversifying farm production and income.

Limited arable land base, stimulates farmers to use a wide range of diverse integrated farming practices and methods, as well as a highly diverse array of species, varieties, cultivars, and traditional and races on their small holdings. A small and medium-sized farmer can realize substantial profits in such integrated agroforestry systems. For example, Figure 8 shows the discounted costs and benefits of the intercropping of walnut with clover/wheat rotation. In such agroforestry option the clover results in losses of $239 \mathrm{USD} / \mathrm{ha}$. Whereas another annual crop - wheat - generates profits of $517 \mathrm{USD} /$ ha over seven years. Walnut is the most profitable crop with the total net present value of $28,015 \mathrm{USD} / \mathrm{ha}$. In the initial years, i.e. during the first and second years, walnut did not bring any benefits and hence this plantation result in losses for land users. The walnut trees started generating profits from year three and increased by almost 25 fold in year nine. When summing the total financial benefits and costs the agroforestry practices generate $28,293 \mathrm{USD} / \mathrm{ha}$.

Figure 8: Discounted cash flow over seven years for intercropping the walnut with clover/wheat rotation

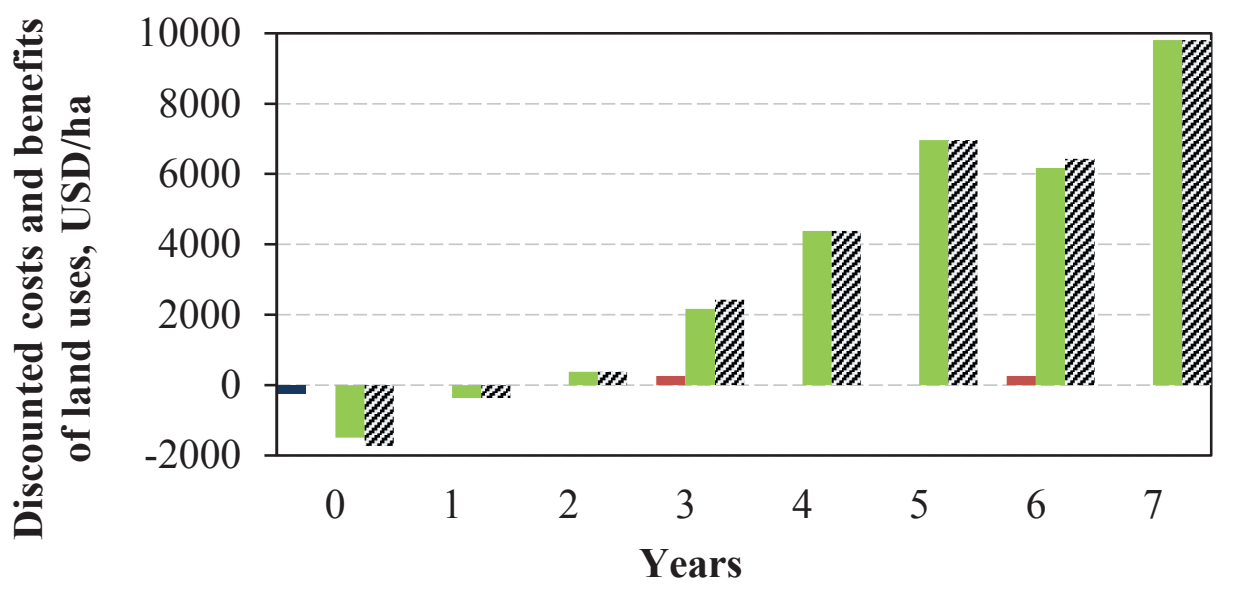

Clover Wheat Walnut $\quad$ W Total income from agroforestry 


\section{Opportunities for agroforestry development}

\section{For rural livelihoods}

Agroforestry provides various products and livelihood opportunities for local people. Diversified agroforestry secures income and cope with market and climate-induced risks and stocks. Agroforestry systems often have higher yield and more profits than the single crop. For example, Djanibekov et al (2012b) showed that afforestation on marginal croplands on-farm would bring the net present values higher than major annual crops such as cotton and wheat (Table 4). According to the analysis done by Djanibekov and Khamzina (in press) and Djanibekov (2014) farm forestry was a viable option to manage agricultural production risks by diversifying land use activities. For example, in the Amu Darya lowlands of Uzbekistan, agroforestry on-farm was shown to be a preferable land use option when irrigation water supply is scarce. In such cases, agroforestry was shown to produce the highest income among land uses.

Table 4: The net present value over seven years of crop cultivation and afforestation on marginal lands.

\begin{tabular}{|l|c|}
\hline \multicolumn{1}{|c|}{ Crops and trees } & USD/ha \\
\hline Cotton & -330 \\
\hline Wheat & -74 \\
\hline Maize & 1,800 \\
\hline Rice & 8,369 \\
\hline E. angustifolia & 5,516 \\
\hline P. euphratica & 1,459 \\
\hline U. pumila & 477 \\
\hline
\end{tabular}

Source: Djanibekov et al (2012b).

Winter foliage is a major issue for smallholder farmers and herders in the region. Tree foliage can provide nutritious feed for livestock, reduce grazing pressure on forestlands, and has the potential to substitute or complement fodder products (Djumaeva et al, 2009). There is also an opportunity to increase the use of tree plantations for commercial purposes providing fruits, nuts, berries, timber and seedlings in larger scales. A variety of available agroforestry systems and approaches, when applied within the context of intensifying small integrated farming systems, especially those which include livestock, can be viable options to address these many issues which face small farms and household production systems in the CAC. For example, Djanibekov et al (2013) showed that from a seven-year rotation of afforestation practices, the household can substantially reduce domestic energy expenditures, and are able to save about 750 USD via harvesting cheaper fuelwood and partially substituting coal and liquefied petroleum gas as compared to the current projections (business-as-usual situation).

\section{For sustainable land management}

Agroforestry technologies can be applied to reclaim degraded lands from agriculture, mining sites, and over-extraction at various scales, from plot to farm level to large agricultural and farming enterprises. Well-selected tree species can fix nitrogen, replenish soil nutrient, and protect from erosion (Figure 9). Generally, these approaches involve either the inter-planting of trees within the agricultural landscape with both economic and environmental benefits, or the use of tree based systems to restore and rehabilitate overused, degraded, abandoned, or otherwise fragile lands.

Inter-cropping of nitrogen fixing trees with crops can improve soil fertility, productivity and increase crop yields. Non-nitrogen fixing trees enhance soil physical, chemical and biological properties by adding above- and belowground organic matter (Jose, 2009). Khamzina et al (2012) concluded that afforestation of highly salinized marginal croplands with fast growing trees in Khorezm, Uzbekistan provides viable options to increase vegetation growth, rehabilitate soil (Figure 10). Planting trees on degraded pastures can provide leaves and branchlets as an alternative source of fodder, protect soil and ground cover from erosion, and rehabilitate the vast areas of these degraded lands across Central Asia. 
Figure 9: Soil conservation advantages of tree planting.

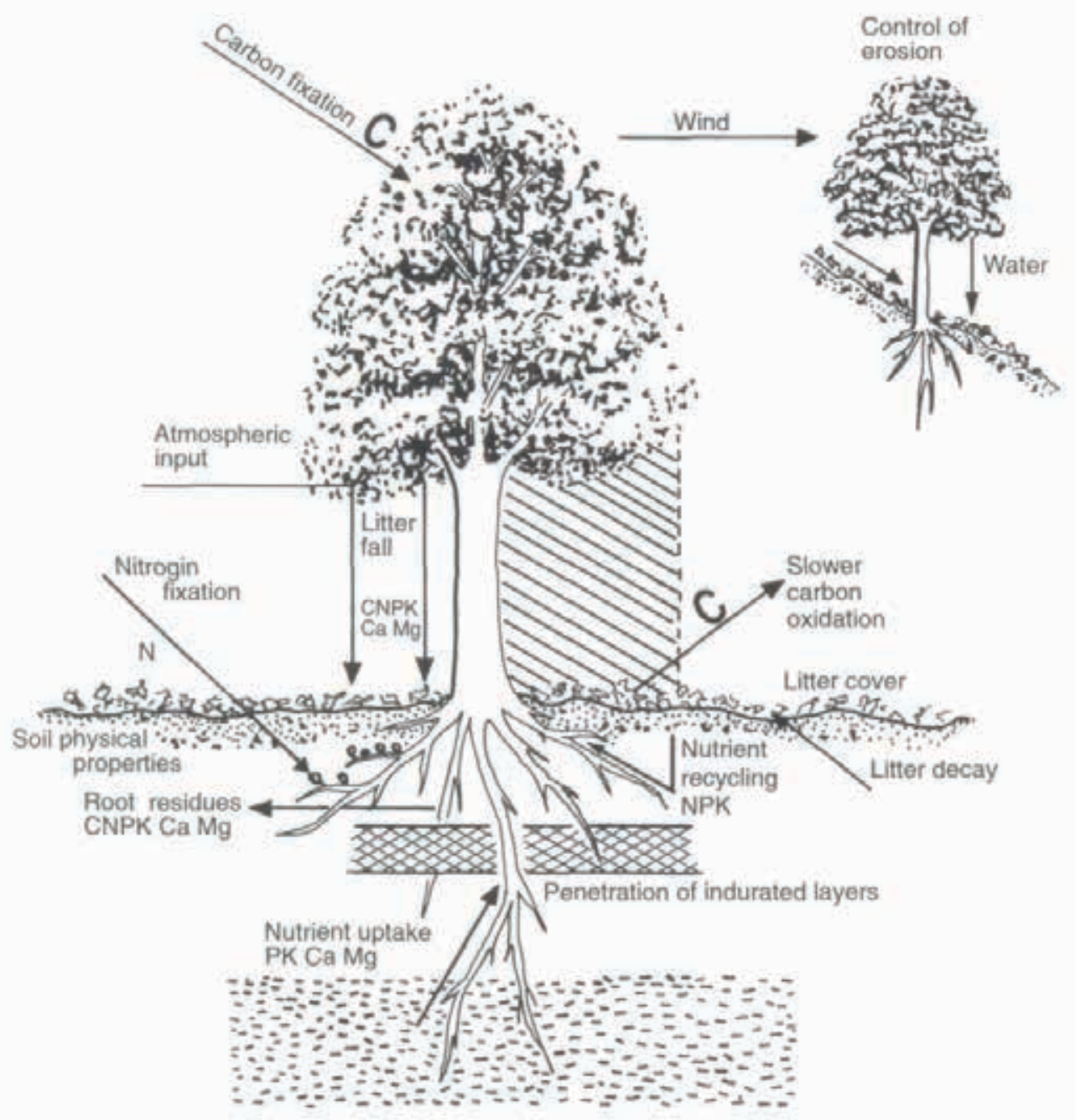

Source: Young (1997)

Figure 10: Afforestation of highly salinized marginal croplands, Khorezm, Uzbekistan
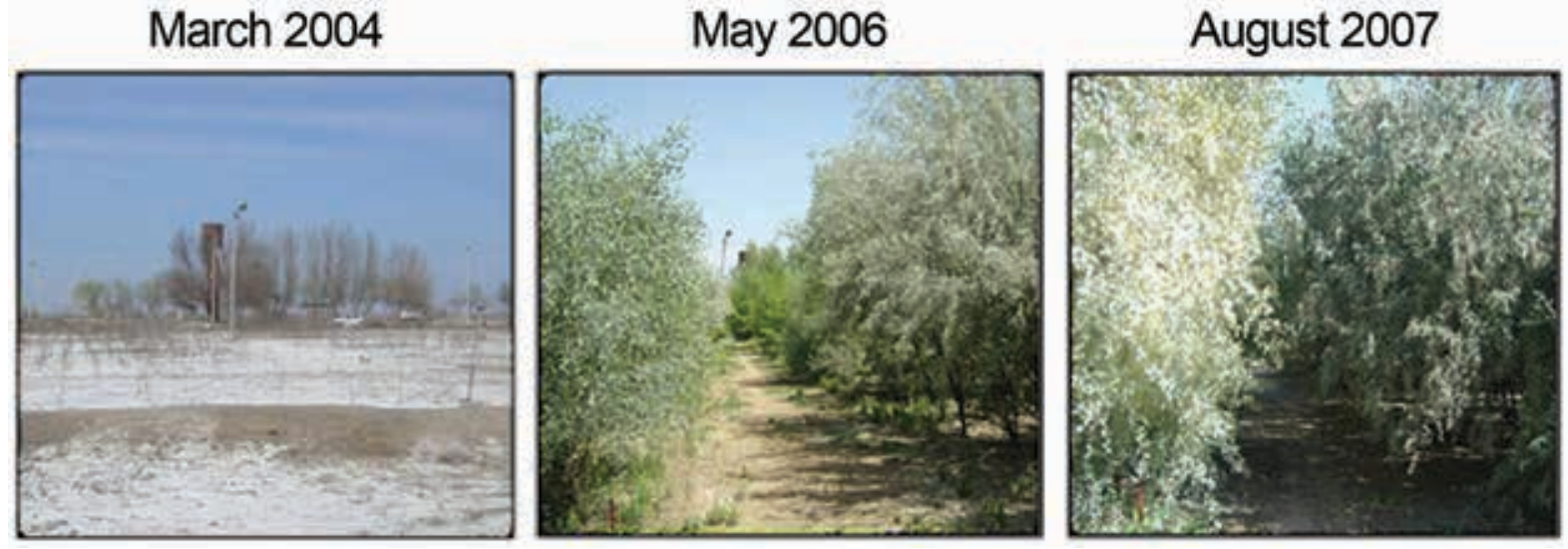

Source: Khamzina et al (2012). 
There are various agroforestry technologies and production systems already available to address sustainable land management issues at the watershed to landscape scale. Tree-based systems are widely employed throughout the world for watershed management, combating desertification, and large-scale land rehabilitation. Various agroforestry, and tree intercropping approaches are employed, as well as fruit and nut production, timber production, and restoration of natural forests.

\section{To protect biodiversity and enhance ecosystem services}

The high demand for timber and fuelwood in the region is satisfied primarily through the illegal harvest from forests (Kleine et al, 2009; Vildanova, 2006). Local farmers began to plant trees on farm for timber and fuelwood production, which significantly reduces the pressure on limited forest resources in Central Asia. Agroforestry has great potential in biodiversity conservation particularly in agricultural biodiversity (McNeely, 2004; Harvey et al, 2006). According to Jose (2009) agroforestry plays five major roles in biodiversity conservation: (1) provides habitat for species; (2) preserves germplasm of sensitive species; (3) reduces the rates of conversion of natural habitat by providing a more sustainable land use; (4) creates corridors between habitat remnants which supports the integrity of these remnants and conservation of floral and faunal species; and (5) conserves biodiversity through the provision of other ecosystem services, e.g. land rehabilitation, prevention of dust spread, and water quality improvement.

Agroforestry at landscape level that create biodiversity friendly agro-ecological matrixes, can create connectivity between remnants, refuges and populations, particularly for migration of animal species and pollination, control pest invasion (Jose, 2009). Agroforestry has great potential for in-situ conservation of important genetic resource particularly the fruits and nuts. Central Asia is origin of domestication of many fruit trees including apples, cherries, apricots, peaches, plums, and other the Prunus spp., and nuts, notably walnuts, pistachios and almonds. Encouraging the economic cultivation of local and endemic cultivars provides an opportunity to provide viable in-situ conservation options for this globally significant treasure of genetic diversity.

With environmental degradation and dry-out of the Aral Sea, sand storm and dust becomes big human health challenge. Agroforestry including windbreak, boundary plantings, buffer strips, shortrotation forestry, and other tree-based practices could be a potential approach to deal with the spread and impact of dust from the Aralkum desert. Vegetative buffers filter airstreams of particulates by removing sand, aerosols, and other particulates and gases that are harmful to human health and agricultural production.

Agroforestry can also serve as biological remediation of non-point source of pollution such as overuse of fertilizers from agriculture and heavy metal contamination from mining industry (Cassman, 1999; He et al, 2013). Trees with deep root system can improve groundwater quality whereby the excess nutrients that have been leached below the rooting zone of agronomic crops are taken up by tree roots. Consequently, these nutrients are recycled back via turnover and litterfall (Van Noordwijk et al, 1996), therefore improving watershed function.

\section{For adaptation and mitigation to climate change}

Trees on farms help adapt to climate change by reducing vulnerability to climate impacts and confronting climate change (McGray et al, 2007). Trees on farms can mitigate the effects of weather extremes such as droughts or heavy rain. According to Ma et al (2009) the tree components of agroforestry systems stabilize the soil against landslides and raise infiltration rates to limit surface flow during the rainy season and increase groundwater release during the dry season. With rainfall intensities expected to rise with climate change (IPCC, 2007), this feature of agroforestry systems to avert landscape degradation will become more important as climate changes in the future. 
Tree contributes to large slope stability in the mountains. Many trees such as walnut have deep and extensive root network. Mubalieva and Aknazarov, (2010) suggest, as almost 97 percent of Tajikistan is mountainous, the slopes could be planted with rows of mulberry while the alleys are planted with barley or lucerne, which will improve soil fertility and protect slopes. Dragavtsev (1947) proposed to use sloping lands of mountain and hills preferably for fruit orchard plantations and tree interrow spaces for fodder grass. In this case, the tree component stabilizes the soil, and the inter-space vegetative cover prevents soil erosion and landslides from water and wind. The wide network of tree root system protects from soil and water erosion, and more significantly reduce landslides and gully erosion (Muhamedshin, 1977).

Carbon sequestered by trees and stored in aboveground biomass and belowground soil contributes to reducing greenhouse gas concentrations in the atmosphere. The estimated technical carbon sequestration potential of agroforestry systems varies tremendously, ranging from under $100 \mathrm{Mt}$ $\mathrm{CO}_{2}$ e per year by 2030 (Smith et al, 2007) to over $2000 \mathrm{Mt} \mathrm{CO}_{2}$ e per year over a 30 year period (Verchot et al, 2007), but agroforestry systems tend to sequester much greater quantities of carbon than agricultural systems without trees (Makumba et al, 2007). Analysis of the spatial distribution of existing agroforestry systems (Zomer et al, 2009) shows a wide potential for increasing tree cover on agricultural lands and rangelands (Kirby and Potvin, 2007).

The agriculture in Central Asia has to live up to a triple challenge: raise food production and generate more income per unit area; reduce climate-induced risks (both too much water and too little water); and reduce greenhouse gas emissions from agriculture. Agriculture with trees is ideally placed to tackle all three challenges. Using the appropriate agroforestry species can even provide fodder and shade for animals and protection of the soil against irradiation during the dry season while providing organic fertilizers for the annual crops during the rainy season. In case that a drought destroys the annual crop, the trees will still provide fruits, fodder, firewood, timber and other products that often achieve high commercial value.

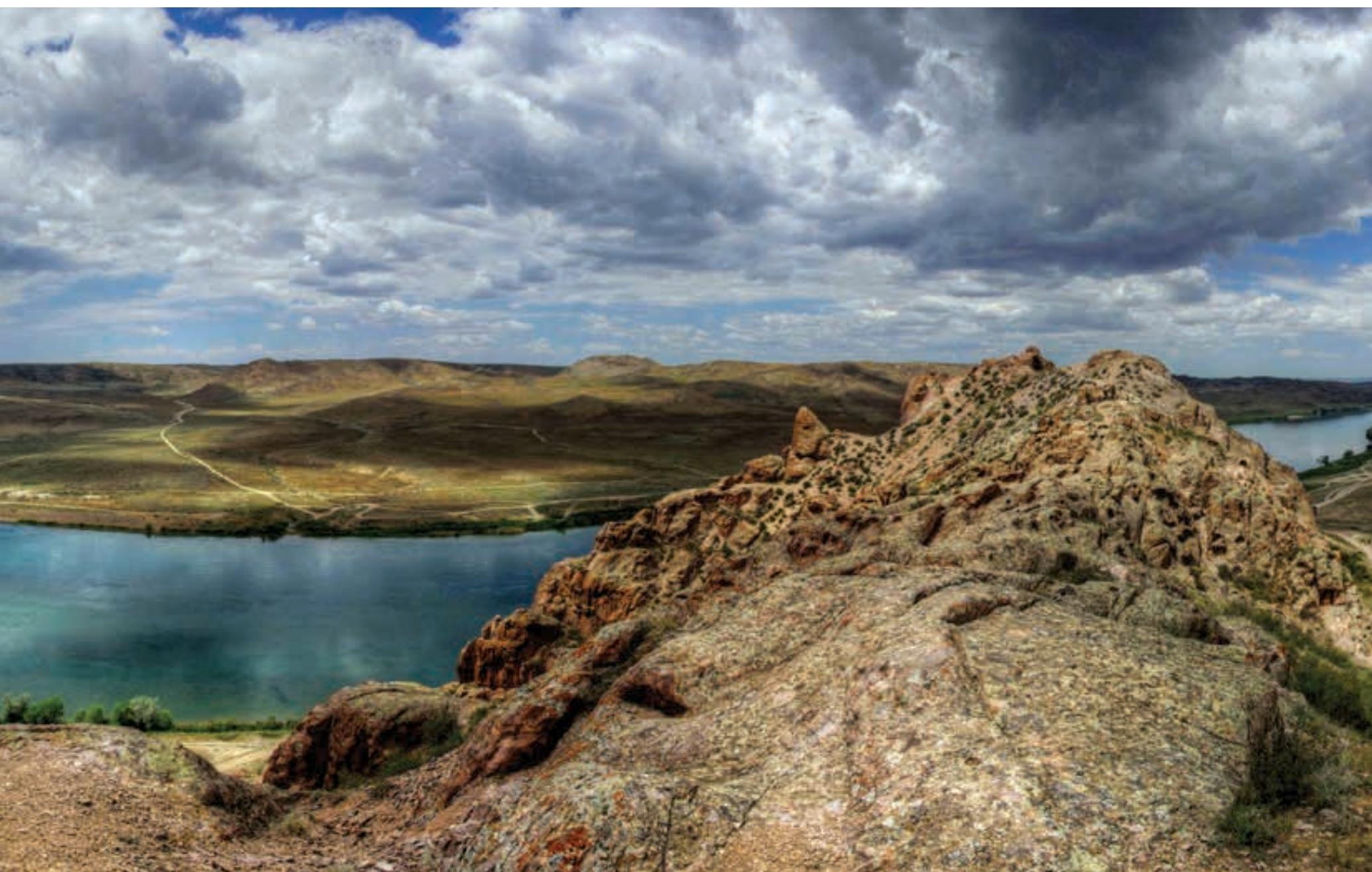




\section{Constraints of agroforestry}

\section{Lack of knowledge}

In spite of the many advantages, and the use of agroforestry in the past and in nearby countries, these approaches, even though they are often incorporated into farming practices found in the region, are not widely recognized for their potential contribution to the agricultural sector, or for their potential role in sustainable land management. There are significant and substantial constraints for the adoption of agroforestry practices and systems. One of the main challenges faced by farmers interested to adopt various agroforestry approaches is initial high cost and delayed economic returns. However, many of the added ecosystem services of agroforestry are not well known or neglected. For instance, Djanibekov (2015) concluded from farm surveys in north-western Uzbekistan that farmers were not familiar with the range of ecosystem services provided by agroforestry activities. Consequently, their perceived value was low.

Lack of knowledge about the benefits of agroforestry may be due to its novelty as an alternative farming system. Although research and some types of agroforestry exist, agroforestry needs to be viewed as an individual discipline. There is a need to share knowledge among farmers regarding the best practices of agroforestry and best possible combination of species on their land. Lapeña et al (2014) mention the absence of specialized skills in fruit growing and tree grafting, ascribing it to a lack of access to advisory services and a lack of communication between academic and research organizations. From a policy intervention point of view, lack of awareness about agroforestry advantages and its possible fields of implementation could hinder the adoption of agroforestry practices by farmers, and complicate the decision-making processes on higher levels. There is a need for more training and knowledge dissemination among all stakeholders in order clarify any possible fields of application as well as difficulties involving agroforestry.

In another study, Messerli (2002) investigated agroforestry in settlements concentrated in valleys at 1000 to 1500 metres above sea level proximal to the walnut-fruit forests and found over 90 different non-timber forest products. Farmers who participated in the study were interested in planting trees and considered non-timber forest products collection as important to their livelihood. Results of the study indicated an increased use of forest leases to local people, allowing them to collect firewood, walnuts and fruits under the condition that they safeguard the forests and participate in afforestation efforts. Farmers embraced the concept of adding more species, including poplar and damson trees as well as apple, pear or rose-hips, peach, apple, pear, cherry and walnut. When the trees grow bigger and sunlight becomes scarcer, they would use the rows for hay (or grazing) and eventually replace this with berries. Orchard development and management was found to be of critical importance (Messerli, 2002).

The limited provision of agricultural machinery to care for trees, lack of equipment to process tree products, lack of financing establishments ensuring funds for woody perennial plantations, and difficulties with storage and transportation of tree products also constrain farmers' willingness to choose new land-use practices (Lapeña et al, 2014). The collapse of the former agricultural extension services has left many agricultural enterprises, small farmers, and rural communities lacking in information and support for improving agricultural production and adopting new varieties and practices. 


\section{Undeveloped markets and long waiting periods to reap the benefits}

One of the main barriers for agroforestry adoption by farmers is its high initial investments and delayed income generation. Agroforestry practices require lots of input during the initial years, and it could take years before farmers break even. For example, according to Djanibekov et al (2012), the afforestation on marginal croplands starts to generate benefits starting only from year three. The interest of obtaining "quick money" fixed many farms' focus on annual crop cultivation.

Local people mostly focus on such production patterns which have higher demand and seem to be more profitable. According to the analysis of Buttoud et al (2013), lack of information from the current markets is another constraint for agroforestry implementation. The market information systems introduced in some CAC countries usually do not include information on tree products. As such, consumers are not fully aware about the tree products available in the market. The markets for tree products are both less efficient and less developed than for crop and livestock commodities. Accordingly, the value chains related to agroforestry systems are also less developed.

\section{Biophysical constraints}

The most intractable constraints are of biophysical nature: the region's scarce amount of arable land, and its aridity. Water availability is a significant problem in CAC, exacerbated by increasing temperatures and glacier melting as a result of climate change processes. Precipitation levels are low and may be insufficient for agroforestry land-use types. There may be a need to develop irrigation networks, but this would drain rivers even more and may continue to desiccate the Aral Sea. Lack of knowledge and limited access to drought-tolerating tree and crop species will further complicate the adoption of agroforestry.

Uncertain status of land quality hinders the process of land transformation. For example, many degraded pastures in Kyrgyzstan provide little biomass. Farmers could apply agroforestry techniques to convert such plots to more valuable land if the location and status of such lands were publicly known.

\section{Policy and institutional restrictions}

The absence of agroforestry as an alternative land use system in the legislations of CAC hinders the adoption of agroforestry. Present land use policy settings pose several constraints for local farmers willing to adopt agroforestry, such as preferential subsidizing of certain crops by providing additional irrigation quotas and fertilizers. Agricultural policies in the CAC still reminisce of Soviet-era strategy. For example, cotton cultivation in Uzbekistan is of high priority for the state. Farmers have to cultivate cotton on about half of the land, produce a certain amount of cotton, and sell the entire harvest to the state at a fixed price (Djanibekov et al, 2010). Such policies reduce farmers' decisionmaking flexibility.

In CAC, land is usually owned by the state and farmers have usufruct rights. It is not allowed to use land plots for agroforestry that are originally designated for another practice, further restricting farmers' land use decisions. In the case of Uzbekistan, failing to deliver state crops may result in the state withdrawing the land from the farmer. Farmers respond by refraining from make long-term investments (such as agroforestry practices) in their farms.

Cutting through huge amounts of red tape further obstructs the adoption of sustainable agroforestry systems in the CAC. Obtaining proper ownership rights and permissions takes lots of effort and time. Soviet-style systems were designed to sustain certain types of agriculture (e.g. cotton and wheat) and are not suited for wide-spread agroforestry adoption. Changing infrastructure, institutions and policies may result in high costs and the fragile transitional state of CAC may discourage governments from bringing about change. 


\section{Recommendations to facilitate agroforestry adoption}

\section{Knowledge dissemination}

Increasing agroforestry practices would require several interventions that differ depending on socioeconomic and agro-ecological conditions of the CAC (Messerli, 2002). Due to the relative novelty of agroforestry, lack of knowledge about the practice and its benefits can be blamed for its slow adoption. Although research and recommendations on agroforestry practices exist, it is not regarded as an individual field of study. Building the research capacity for agroforestry will prove vital for disseminating knowledge about this land-use practice. More field experiments are required, using different scientific methods to analyse the suitability of agroforestry in different areas of the CAC. The research should focus on relevant tree and crop species that can be efficiently combined in forests, farmlands and kitchen gardens. Additionally, economic assessment is essential to value the economic potential of agroforestry alternatives. Socio-economic investigations into farmers' perceptions of agroforestry as a new technique on their farms could help to find proper implementation pathways that are socially and culturally compatible.

Knowledge sharing about best practices and species combinations for agroforestry would be essential. Lapeña et al (2014) mention the absence of fruit growing and tree grafting skills, ascribing it to lack of access to advisory services and lack of communication between academic and research organizations. This highlights the need for better dissemination of knowledge. Farmers' associations can help with this. For example, the Kyrgyz Association of Forest and Land Users serves as a bridge between its members and national government, state agencies, drawing attention to urgent issues and promoting needed laws and regulations for approval at national level. Such organizations that are able to communicate directly with farmers would play a crucial role in the adoption of agroforestry. Village centres, too, can play a crucial role in organizing meetings and training programmes for farmers. Finally, international institutions can help introduce agroforestry management practices from experiences abroad.

\section{Capturing the full economic value of agroforestry}

Providing goods and ecosystem services, agroforestry has a number of advantages not only on a household level, but also on village, country, regional and global levels. Such positive impacts are full-value public goods, contributing to food security and income of the rural population, and need to be regarded as such. Internalizing the added value of goods and services of such land use may increase its financial value. Rewarding the providers accordingly through different (i.e. compliance or regulatory) markets could give a boost to agroforestry adoption (Djanibekov et al, 2012b), and compensate for farmers' start-up time during which no income is generated from tree products.

Appropriate markets need to be developed where farmers can easily sell agroforestry products to boost the economic value of agroforestry. Building storage facilities where tree products can be stored will ensure the quality of products and consumers' trust. Developing a processing sector will further diversify agroforestry products, increasing the demand for and the value of agroforestry practices.

\section{Selecting suitable agro-ecological conditions for agroforestry}

Climate aridity and water availability were identified as natural constraints. Avoiding or tackling these may prove too costly. However, agroforestry can still be practiced in suitable areas. Although the CAC differ in natural conditions, pasture degradation (i.e. erosion, salinization, and low productivity) 
is common to the whole region. Agroforestry can offer silvo-pastoralism as an alternative for local herdsmen. Serving as an additional source of fodder, positively affecting soil and vegetation productivity, and providing shade to relieve livestock from heat stress (resulting in weight and productivity loss), silvo-pastoralism could offer solutions to limited forage resources, forest-pasture conflicts and soil degradation issues.

Another example was provided by Khamzina et al (2012): afforestation in marginal land does not require the irrigation water so much needed for the crops. Instead, trees can use their roots to absorb the groundwater. Furthermore, establishing agroforestry in elevated and slope areas may be more suitable than alternative land uses, such as annual crops.

Thorough suitability assessment should identify the areas suitable for agroforestry and under which conditions. It is also necessary to find out which tree species are adapted to the local environment, which planting combinations optimize pollination and diversity, optimal harvest times, pruning and grafting times, and the amounts and timing of input application.

\section{Policy and institutional support}

National and local incentives are essential to realize the environmental and economic potential of agroforestry and its contribution to sustainable development in the CAC. Agroforestry is relatively novel in the region as a practice and as a research field, which is why agroforestry is absent in the relevant regulations. Legal recognition is therefore necessary to allow agroforestry practices to flourish. The institutional design need to take into the account the enabling options of agroforestry, the actors involved in agroforestry practices, resources required for agroforestry, as well as agroforestry's feedback to these actors and resources.

The multi-dimensional character and multi-level scale of agroforestry (i.e. provision of various ecosystem services at various scales) suggests the establishment of a particular institution, focusing on agroforestry management regulating all interrelations among the named fields and fostering sustainable management, scientific research and dissemination of knowledge.

Flexibility in land use so farmers can decide what and where to cultivate could be equally decisive to initiate agroforestry practices. In particular, a change in the legal status of land rights is essential. When farmers are certain about their land possession, they will be more willing to make long-term investments, such as agroforestry (Djanibekov, 2015).

Land and income tax exemptions may be considered to raise the financial attractiveness of agroforestry in the beginning (Kan et al, 2008). Local support is required to cover initial investments and attract farmers for such land use.). 


\section{References}

AGRIWANET project, 2014. Agricultural Restructuring, Water Scarcity and the Adaptation to Climate Change in Central Asia: A Five-Country Study. IAMO, Halle (Saale).

Alibekov, L.A., 2000. Mountain deforestation in Middle Asia and agroforest ameliorations. Oecologia Montana 44-47.

Bobojonov, I., Aw-Hassan, A., 2014. Impacts of climate change on farm income security in Central Asia: An integrated modeling approach. Agriculture, ecosystems \& environment 188, 245-255.

Brück, T., Esenaliev, D., Kroeger, A., Kudebayeva, A., Mirkasimov, B., Steiner, S., 2013. Household survey data for research on well-being and behavior in Central Asia. Journal of Comparative Economics 42 (3), 819-835.

Bucknall, J., Klytchnikova, I., Lampietti, J., Lundell, M., Scatasta, M., Thurman, M., 2003. Irrigation in Central Asia: social, economic and environmental considerations. World Bank, Europe and Central Asia Region, Environmentally and Socially Sustainable Development.

Bulichev A.S., Onischenko L.P., 1979. Field protection wind-breaks in Chuy valley and their efficiency, Frunze.

Burkhanov, A., 2014. Effect of Xaloxylon plantations on pastures in Kyrgyzstan. Conference on Agroforestry Pracrices in Central Asia, MSRI/UCA, Kyrgyzstan.

Buttoud, G; Place, F; Gauthier, M., 2013. Advancing agroforestry on the policy agenda: a guide for decision-makers: Food and Agriculture Organization of the United Nations.

Cassman, K.G., 1999. Ecological intensification of cereal production systems: Yield potential, soil quality, and precision agriculture. Proceedings of the National Academy of Sciences 96, 59525959.

Chen, X., Bai, J., Li, X., Luo, G., Li, J., Li, B.L., 2013. Changes in land use/land cover and ecosystem services in Central Asia during 1990-2009. Current Opinion in Environmental Sustainability 5, 116-127.

Conservation International (CI), 2008. Biodiversity Hotspots: Mountains of Central Asia. Conservation International, Washington, DC, USA. Available at: http://www.biodiversity hotspots. org/xp/hotspots/central_asia/ [accessed 3 September 2008].

Cornet J.G., Rajapbaev, M., 2004. Criteria and Indicators for the Sustainable Management of Juniper Forests in South Kyrgyzstan. Nancy, Ecole Nationale du Génie Rural, des Eaux et des Forêts, Commission of the European Communities, Artcha JUMP Project.

Djanibekov, N., Rudenko, I., Lamers, J. P. A., Bobojonov, I., 2010. Pros and Cons of Cotton Production in Uzbekistan. In Pinstrup-Andersen, P., Cheng, F. (Eds.): Food Policy for Developing Countries: Food Production and Supply Policies (Ithaca, NY, Cornell University Press).

Djanibekov, N., Van Assche, K., Bobojonov, I., Lamers, J.P.A., 2012a. Farm Restructuring and Land Consolidation in Uzbekistan: New Farms with Old Barriers. Europe-Asia Studies 64, 1101-1126.

Djanibekov, N., Wolz, A., 2015. Development dilemma in Central Asia: Need, but high constraints in establishing agricultural service cooperatives. In IAMO (Ed.), IAMO 2015, Halle (Saale). available at www.iamo.de

Djanibekov, U., 2014. Trees, crops, and rural livelihoods: Afforestation of marginal croplands in Uzbekistan. Universitäts-und Landesbibliothek Bonn. 
Djanibekov, U., 2015. A co-evolutionary perspective on the adoption of sustainable land use practices: The case of the Amu Darya River lowlands, Uzbekistan. In Beunen, R., Van Assche, K., Duineveld, M. (Eds.): Evolutionary governance theory: Theory and applications. Springer International Publishing, Switzerland, pp. 233-245. DOI: 10.1007/978-3-319-12274-8_16.

Djanibekov, U., Djanibekov, N., Khamzina, A., Bhaduri, A., Lamers, J.P.A., Berg, E., 2013. Impacts of innovative forestry land use on rural livelihood in a bimodal agricultural system in irrigated drylands. Land Use Policy 35, 95-106.

Djanibekov, U., Khamzina, A., Djanibekov, N., Lamers, J.P.A., 2012b. How attractive are short-term CDM forestations in arid regions? The case of irrigated croplands in Uzbekistan. Forest Policy and Economics 21, 108-117.

Djanibekov, U., Khamzina, A., (in press). Stochastic Economic Assessment of Afforestation on Marginal Land in Irrigated Farming System. Environmental and Resource Economics. DOI: 10.1007/s10640-014-9843-3.

Dzhakypbekova K., 2014. Potential of Agroforestry Systems in Kyrgyzstan. Master Thesis, Bishkek, Kyrgyzstan.

Djumaeva, D.M., Djanibekov, N., Vlek, P., Martius, C., Lamers, J., 2009. Options for optimizing dairy feed rations with foliage of trees grown in the irrigated drylands of Central Asia. Research Journal of Agriculture and Biological Sciences 5, 698.

Dragavtsev, A.P., 1947. Planting of fruit trees in mountainous conditions of Zailiy Ala-Tau. Library of Kyrgyz National Academy of Science.

Dubovyk, O., Menz, G., Conrad, C., Kan, E., MaChwitz, M. Khamzina, A., 2013. Spatio temporal analyses of cropland degradation in the irrigated lowlands of Uzbekistan using remote-sensing and logistic regression modeling. Environmental Monitoring and Assessment 185 (6), 4775-4790. DOI: $10.1007 / \mathrm{s} 10661-012-2904-6$.

Dukhovny, V.A., Ziganshina, D., 2011. Ways to improve water governance. Irrigation and Drainage $60,569-578$.

Eastwood, A., Lazkov, G., Newton, A.C., 2009. The red list of trees of Central Asia. Fauna \& Flora International, Cambridge, UK.

El Beltagy, A., 2002. ICARDA'S experience in rehabilitation of degraded drylands in Central and Western Asia and Northern Africa. In Lee, K., Schaaf, T. (Eds.), Rehabilitation of degraded drylands and biosphere reserves. Proceedings of international workshop on Combating Desertification. UNESCO-MAB Drylands Series, Aleppo, pp. 1-4.

Engel, S., Pagiola, S., Wunder, S., 2008. Designing payments for environmental services in theory and practice: An overview of the issues. Ecological Economics 65, 663-674.

Eshchanov, B.R., Stultjes, M.G.P., Salaev, S.K., Eshchanov, R.A., 2011. Rogun Dam-Path to Energy Independence or Security Threat? Sustainability 3, 1573-1592.

Eurostat, 2010. Agricultural census 2010.

FAO, 2006a. People, Forests and Trees of West and Central Asia: Outlook for 2020. FAO Forestry Paper No. 152. FAO, Rome, Italy.

FAO, 2006b. Global Forest Resources Assessment 2005: Progress Towards Sustainable Forest Management. FAO Forestry Paper No. 147. FAO, Rome, Italy.

FAO, 2012. Bulletin on food security of Kyrgyzstan: FAO Representation in Kyrgyzstan.

FAO, 2014. FAO Statistical Database. Last accessed on 02.12.2014. 
Field, N., 1954. The Amu Darya: a study in resource geography. In: Geographical Review 44, 528 542. DOI: $10.2307 / 212158$.

Fisher, R.J., Schmidt, K., Steenhoof, B., Akenshaev, N., 2004. Poverty and Forestry: A Case Study of Kyrgyzstan with Reference to Other Countries in West and Central Asia. FAO Livelihood Support Programme, Working Paper 13. FAO, Rome, Italy.

Fischer, G., Tubiello, F.N., van Velthuizen, H., Wiberg, D.A., 2007. Climate change impacts on irrigation water requirements: Effects of mitigation, 1990-2080. Technological Forecasting and Social Change 74, 1083-1107.

Gupta, R., Kienzler, K., Martius, C., Mirzabaev, A., Oweis, T., de Pauw, E., Qadir, M., Shideed, K., Sommer, R., Thomas, R., 2009. Research prospectus: a vision for sustainable land management research in Central Asia. ICARDA Central Asia and Caucasus program. Sustainable agriculture in Central Asia and the Caucasus series 1, 84 .

Gusev, P.P., 1938. Forest-gardens (issues of cultivating wild fruit trees). Moscow.

Hansen, M. C., Potapov, P. V., Moore, R., Hancher, M., Turubanova, S. A., Tyukavina, A., Thau, D., Stehman, S. V., Goetz, S. J., Loveland, T. R., Kommareddy, A., Egorov, A., Chini, L., Justice, C. O., Townshend. J. R. G., 2013. High-Resolution Global Maps of 21st-Century Forest Cover Change. Science 342 (15 November): 850-53. Data available on-line from: http:// earthenginepartners.appspot.com/science-2013-global-forest.

Harris, S.A., Robinson, J.P., Juniper, B.E. 2002. Genetic Clues to the Origin of the Apple. Trends in Genetics, 18(8), 426-430.

Harvey, C.A., Gonzalez, J., Somarriba, E., 2006. Dung beetle and terrestrial mammal diversity in forests, indigenous agroforestry systems and plantain monocultures in Talamanca, Costa Rica. Biodiversity \& Conservation 15, 555-585.

Hawkes, J.G., 1998. Back to Vavilov: Why Were Plants Domesticated in Some Areas and Not in Others? In: The Origins of Agriculture and Crop Domestication. In Damania, A.B., Valkoun, J., Willcox, G. and Qualset, C.O. (Eds.). ICARDA, Aleppo, Syria.

He, L., Fang, X., Meng, G., Li, G., Shao, J., Chai, Y., Kong, J., 2013. Effect of Alnus nepalensis cultivation on soil biological and physicochemical properties during restoration near a phosphate smelter in Kunyang, Yunnan Province, SW China. Journal of soil science and plant nutrition 13, pp. 355-366.

IRIN, 2003. Kyrgyzstan: Focus on Deforestation in the South. UN Humanitarian News and Information Service. Available at: http://www.irinnews.org/Report.aspx?ReportId=20728 [accessed 10 September 2008].

IUCN, 2010. Centres of Plant Diversity: A Guide and Strategy for their Conservation. Vol. 2: Asia, Australia and the Pacific. WWF and IUCN, Gland, Switzerland.

Izac, A., Schroth, G., Sinclair, F., 2002. Economic aspects of soil fertility management and agroforestry practices. Trees, crops and soil fertility: concepts and research methods, 13-37.

Jose, S., 2009. Agroforestry for ecosystem services and environmental benefits: an overview. Agroforestry Systems 76, 1-10.

Kamelin, R.V., 2002. Foreword. In: Umbelliferae (Zontichnye) of Kyrgyzstan (eds Pimenov, M.G., Kamelin, R.V. and Kliuikov, E.V.). KMK Scientific Press, Moscow, Russia. (from Eastwood, 2009). 
Kan, E., Lamers, J.P.A., Eshchanov, R., Khamzina, A., 2008. Small-scale farmers' perceptions and knowledge of tree intercropping systems in the Khorezm region of Uzbekistan. Forests, trees and livelihoods $18,355-372$.

Kaplan, S., Blumberg, D.G., Mamedov, E., Orlovsky, L., 2014. Land-use change and land degradation in Turkmenistan in the post-Soviet era. Journal of Arid Environments 103, 96-106.

Khamzina, A., Lamers, J.P.A., Vlek, P.L.G., 2012. Conversion of degraded cropland to tree plantations for ecosystem and livelihood benefits, in: Martius, C., Rudenko, I., Lamers, J.P.A., Vlek, P.L.G. (Eds.): Cotton, Water, Salts and Soums - Economic and Ecological Restructuring in Khorezm, Uzbekistan. Springer, Dordrecht, Heidelberg, London, New York.

Kirby, K.R., Potvin, C., 2007. Variation in carbon storage among tree species: implications for the management of a small-scale carbon sink project. Forest Ecology and Management 246, 208-221.

Kleine, M., Colak, A., Kirca, S., Sagheb-Talebi, K., Orozumbekov, A., Lee, D., 2009. Rehabilitating degraded forest landscapes in West and Central Asia. IUFRO World Series 20, 5-26.

Kremen, C., 2005. Managing ecosystem services: what do we need to know about their ecology? Ecology letters 8, 468-479.

Lapeña, I., Turdieva, M., López Noriega, I., Ayad, W.G., 2014. Conservation of fruit tree diversity in Central Asia: Policy options and challenge; Bioversity International.

Lerman, Z., 2009. Land reform, farm structure, and agricultural performance in CIS countries. China economic review 20, 316-326.

Lioubimtseva, E., 2014. Impact of climate change on the Aral Sea and its Basin, The Aral Sea. Springer, pp. 405-427.

Lioubimtseva, E., Cole, R., Adams, J.M., Kapustin, G., 2005. Impacts of climate and land-cover changes in arid lands of Central Asia. Journal of Arid Environments 62, 285-308.

Lioubimtseva, E., Henebry, G.M., 2009. Climate and environmental change in arid Central Asia: Impacts, vulnerability, and adaptations. Journal of Arid Environments 73, 963-977.

Ma X., Xu J.C., Luo, Y., Aggrawal, S.P., Li J.T., 2009. Response of hydrological processes to landcover and climate changes in Kejie watershed, south-west China. Hydrological Processes. Online. DOI: 10.1002/hyp.7233

Malsy, M., Aus der Beek, T., Eisner, S., Flörke, M., 2012. Climate change impacts on Central Asian water resources. Advances in Geosciences 32, 77-83.

McGray, H., Hammill, A., Bradley, R., Schipper, E.L., Parry, J.E., 2007. Weathering the Storm: Options for Framing Adaptation and Development. World Resources Institute, Washington DC.

McNeely, J., 2004. Nature vs. nurture: managing relationships between forests, agroforestry and wild biodiversity. Agroforestry Systems 61, 155-165.

MEP, 1998. Republic of Kyrgyzstan Biodiversity Strategy and Action Plan. Ministry of Environmental Protection, Bishkek, Kyrgyzstan.

Messerli, S., Yuldashev, U., 2000. Trees and agriculture in walnut forests in South Kyrgyzstan: present state and potential for agroforestry, Bishkek.

Messerli, S., 2002. Agroforestry-a way forward to the sustainable management of the Walnut Fruit Forests in Kyrgyzstan. Schweizerische Zeitschrift fur Forstwesen 153, 392-396.

Micklin, P., 2002. Water in the Aral Sea Basin of Central Asia: Cause of Conflict or Cooperation. Eurasian Geography and Economics, No. 7, pp. 505-528. 
Micklin, P., 2007. The Aral sea disaster. Annu. Rev. Earth Planet. Sci. 35, 47-72.

Micklin, P., 2010. The past, present, and future Aral Sea. Lakes \& Reservoirs: Research \& Management 15, 193-213.

Mirzabaev, A., 2013. Climate Volatility and Change in Central Asia: Economic Impacts and Adaptation. Universitäts-und Landesbibliothek Bonn.

MNPT, 2002. Biodiversity Strategy and Action Plan for Turkmenistan. Ministry of Nature Protection of Ashgabat, Turkmenistan.

Mubalieva, Sh.M., Aknazarov, O.A., 2010. Technology of planting mulberry gardens on mountain slopes of Western Pamir (Recommendation), Bioversity International/UNEP-GEF, Khorog.

Muhamedshin, K.D., 1977. Juiper forests of Tian-Shan and their role in the forestry. Frunze.

Nair, P.K.R., 1985. Classification of agroforestry systems. In Agroforestry Systems (3), pp. 97-128.

Nair, P.K.R., 1993. An Introduction to Agroforestry. Dordrect, Netherlands: Kluwer Academic Publishers.

National Environment Report of Kyrgyz Republic for 2006-2011, UNDP/UNEP, 2012, p. 69.

Nations Online Project. http://www.nationsonline.org/oneworld/index.html (last accessed: 01.12.2014).

Nurgaziev, R.Z., Ajibekov, A.S., Mansurova, A.M., 2013. Sustainable food system - a tool for food security. World Food Day Conference in Kyrgyz National Agrarian University.

O'Hara, S.L., 1997. Irrigation and land degradation: implications for agriculture in Turkmenistan, Central Asia. Journal of Arid Environments 37(1), 165-179.

Pender, J., Mirzabaev, A., Kato, E., 2009. Economic Analysis of Sustainable Land Management Options in Central Asia. Final report for the ADB. IFPRI/ICARDA, 168.

Pomfret, R., 2010. Constructing market-based economies in Central Asia: A natural experiment? The European Journal of Comparative Economics 7, 449-467.

Popov, M. G.; Klabukov, A. G.; Malkovsky, M. P., 1935. Wild fruit brushwoods in Alma-Ata vicinity of Zailiy Alatau (Tian-Shan). Alma-Ata.

Prutensky, D.I., 1962. Practice of cultivating wild fruit trees in walnut-fruit forests in Kyrgyzstan. Frunze.

Rehnus, M., Mamadzhanov, D., Venglovsky, B.I., Sorg, J-P., 2013. The importance of agroforestry hay and walnut production in the walnut-fruit forests of southern Kyrgyzstan. Agroforestry systems $87(1), 1-12$.

Rowe, W.C., 2009. "Kitchen Gardens" in Tajikistan: The Economic and Cultural Importance of SmallScale Private Property in a Post-Soviet Society. In Human ecology 37 (6), pp. 691-703.

Safarov, N., 2003. Republic of Tajikistan: National Strategy and Action Plan on the Conservation and Sustainable Use of Biodiversity. Government of the Republic of Tajikistan, Dushanbe, Tajikistan.

Saiko, T.A., Zonn, I.S., 2000. Irrigation expansion and dynamics of desertification in the Circum-Aral region of Central Asia. Applied Geography 20, 349-367.

Simonett, O., Novikov, V., 2010. Land Degradation and Desertification in Central Asia: Central Asian Countries Initiative for Land Management, Analysis of the current state and recommendation for the future. Zoï Environment Network for the Swiss GEF Council Member, Geneva. 
Spoor, M., 1993. Transition to market economies in former Soviet Central Asia: Dependency, cotton, and water. European Journal of Development Research 5 (2); 142-58.

TEEB, 2011. The Economics of Ecosystems and Biodiversity in Business. Earthscan, London

Tupitsa A., Lamers J., Wobes M., Martius C., 2006. The functional assessment of tree windbreaks in Khorezm, Uzbekistan, Aral Sea Basin, Tropentag, Bonn, Germany.

Undeland, A., 2012. The Development Potential of Forests in the Kyrgyz Republic. Washington, DC: Program on Forests (PROFOR).

Van Noordwijk, M., Lawson, G., Soumare, A., Groot, J., Hairiah, K., 1996. Root distribution of trees and crops: competition and/or complementarity, in: Ong CK, P, H. (Eds.), Tree-Crop interactions: a physiological approach. CAB International, Wallingford, UK, pp. 319-364.

Velandia, M., Rejesus, R.M., Knight, T.O., Sherrick, B.J., 2009. Factors affecting farmers' utilization of agricultural risk management tools: The case of crop insurance, forward contracting, and spreading sales. Journal of Agricultural and Applied Economics 41, 107-123.

Vildanova, G., 2006. Forest and forest products: Country profile Uzbekistan. Geneva timber and forest discussion paper 45. ECE/TIM/DP/45, p. 68.

WOCAT database. Available online at https://qt.wocat.net/qt_summary.php?qt_id=166.

World Bank, 2014. World Development Indicators 2014. The World Bank, Washington, USA.

World Bank Database, 2014. Last accessed on 11.10.2014.

Young A., 1997. Agroforestry for soil management. 2nd ed. Wallingford: CAB International.

Zomer, R.J., Trabucco, A., Coe, R., Place, F., 2009. Trees on farm: analysis of global extent and geographical patterns of agroforestry. World Agroforestry Centre, Nairobi, Kenya.

Zomer, R.J., Trabucco, A., Coe, R., Place, F., van Noordwijk, M., Xu, J., 2014. Trees on farms: an update and reanalysis of agroforestry's global extent and socio-ecological characteristics. Working Paper 179. World Agroforestry Centre, Bogor, Indonesia. DOI: 10.5716/WP14064.

Zomer, R.J.; Wang, M.; and Xu, J., 2015. Projected climate change and impact on bioclimatic conditions in Central and South-Central Asia. ICRAF Working Paper 187. World Agroforestry Centre East and Central Asia, Kunming, China. pp 50. DOI: 10.5716/WP14144. 


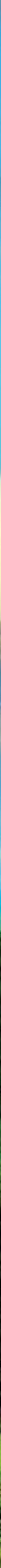


The World Agroforestry Centre is an autonomous, non-profit research organization whose vision is a rural transformation in the developing world as smallholder households increase their use of trees in agricultural landscapes to improve food security, nutrition, income, health, shelter, social cohesion, energy resources and environmental sustainability. The Centre generates science-based knowledge about the diverse roles that trees play in agricultural landscapes, and uses its research to advance policies and practices, and their implementation that benefit the poor and the environment. It aims to ensure that all this is achieved by enhancing the quality of its science work, increasing operational efficiency, building and maintaining strong partnerships, accelerating the use and impact of its research, and promoting greater cohesion, interdependence and alignment within the organization.

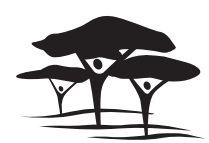

United Nations Avenue, Gigiri • PO Box 30677 • Nairobi, $00100 \cdot$ Kenya Telephone: +254207224000 or via USA +1 6508336645 Fax: +254207224001 or via USA +1 6508336646

Email: worldagroforestry@cgiar.org•www.worldagroforestry.org

East and Central Asia Regional Programme

\% Kunming Institute of Botany • 3/F North Research Building Heilongtan • 650201 Kunming • Yunnan Province • P.R. China Telephone: +86-871-6522-3014 • Fax: +86-871-6522-3377

Email: s.vandemoortel@cgiar.org • www.worldagroforestry.org/eca 